\title{
Dual-Function Forests in the Returning Farmland to Forest Program and the Flexibility of Environmental Policy in China
}

\begin{abstract}
The Returning Farmland to Forest Program (RFFP; tuigeng huanlin gongcheng), which compensates farmers for cultivating forest on previously non-forested land, is central among the "ecological construction" programs that have transformed landscapes across China. Under the RFFP, the state has redefined large areas of land as afforestation area intended to provide environmental services including erosion control, carbon sequestration, and biodiversity regeneration. Tensions among the program's social and environmental objectives as well as the combination of formal rigidity and practical flexibility manifest in ambiguous forest classifications and tremendous variation in outcomes. The RFFP centers on two forest categorizations: ecological forest, intended to rehabilitate environmental services, and commercial forest, which may provide lesser ecological benefits but delivers more immediate economic benefits to households. RFFP policy documents designate "dual-function species" that can be planted as "forests with a primary goal of ecological service provision which also generate commercial value." A substantial portion of "ecological forests" are dual landscapes intended to accomplish both environmental and socioeconomic goals. Drawing from cases in Yunnan, Sichuan, and Hainan provinces, this paper examines the processes of central policymaking and local implementation through which dual-function forests have proliferated, showing how rural residents have responded to the risks and promises of dual-function forests and exploring implications for rural livelihoods and landscapes. While they might be expected to bring win-win outcomes, the performance of dual-function forests on social and environmental goals depends on how local officials and residents respond to the program. Their proliferation demonstrates tensions inherent in state projects aimed at generating both environmental and economic values from rural landscapes.
\end{abstract}

\section{Keywords}

China; Forest; Reforestation; Ecological Restoration; Environmental Policy; Agriculture 


\section{Introduction}

In spite of the common perception that its economic growth has led to unmitigated environmental catastrophe, China has reversed a long history of forest loss, nearly doubling its forested area from 115 Mha in 1981 to about 210 Mha today (Robbins and Harrell, 2014). Since 1999, the tuigeng huanlin gongcheng or Returning Farmland to Forest Program (RFFP; also translated as Sloping Land Conversion Program or Grain for Green Program) has contributed to these gains. The RFFP provides compensation to rural households for planting trees on marginal cropland and uncultivated 'wastelands' in service of goals to increase forest cover, control soil erosion, alleviate poverty, and transform rural livelihoods. By 2013, authorities had invested over 320 billion RMB (US\$50B) to afforest over 29 million hectares, affecting 32 million households (State Forestry Administration, 2013, 2014). Observers have characterized the RFFP as the world's largest program of payments for ecosystem services (PES) (Groom et al., 2010; Liu et al., 2008; Yin, et al., 2014) and a paragon of effective environmental policy (State Forestry Administration, 2013, 2014).

Yet the effectiveness of the RFFP is debated. Researchers and officials have claimed that figures for forested area are exaggerated, that many forests are of inferior quality, that species selection and site selection have been inappropriate, that farmers' participation is coerced, that local officials have diverted funds intended for compensation, or that farmers have not maintained the newly planted forests.

These controversies and the discrepancies that underlie them are rooted in the multiple goals of forest policy. Chinese forest policy since the 1990s has pursued three goals that sometimes align and sometimes conflict: providing a stable supply of forest products, improving rural livelihoods, and preserving and restoring ecosystems. Different stakeholders prioritize these goals differently. Thus implementation raises tensions that result in processes of accommodation, resistance, negotiation, and policy revision.

One outcome of this process is the creation of "dual-function forests," forest plantations formally designated as "ecological forests" for environmental rehabilitation, but planted with commercial tree crop varieties, which account for as much as one-third of RFFP area in provinces for which statistics are available (see Yan and Min, 2004; Zhang and Zuo, 2004). Dualfunction forests present a particular set of compromises among the three overlapping goals of forest policy.

Critical scholars have presented the RFFP and related projects as instances of modernist simplification whose rigid imposition of rules and definitions provokes resistance from residents and unintended changes in landscapes (Schmitt, 2014; see Scott, 1998). Others see instruments of governmentality, cultivating discipline in human populations in efforts to extend state control (Yeh, 2009, 2005). In either picture, state projects arrive in rural communities as overwhelming forces that compel residents to comply as "good subjects" or cope through subtle acts of resistance. Rural residents get tied into performing duties to cultivate economically productive and environmentally protective landscapes.

We claim that the processes surrounding dual-function forests present a different picture, in which state intervention is flexible - we might even say responsive. As officials grappled with the challenges of getting trees in the ground, they needed to adapt to on-the-ground realities. 
These included tradeoffs between environmental goals and local livelihoods, resurgent productivist projects, and the vagaries of biophysical systems. Official policy adjustments were less the imposition of top-down designs than dialogue among policymakers, "muddling through" in pursuit of multiple priorities (Lindblom, 1959) and other actors, including rural residents, local officials, and firms. This dialogue brought compromises that changed the meanings of the RFFP. When state authorities redefined "ecological forests" to include cash crop varieties planted in dual-function forests, they recast the program's role vis-à-vis forest policy goals.

We might expect this compromise to have led to successful tree cultivation, as prospective gains persuaded residents to embrace tree crops. But our field research in south and southwestern China shows that such was not always the case. We highlight four mechanisms involved in the varied results of dual-function forests. First, local officials varied in their responses. Flexibilities of the RFFP combined with resource constraints, cadre performance imperatives, and concerns with stability (Eaton and Kostka, 2014; Lee and Zhang, 2013) to lead to differing local implementation. Central policy flexibility did not prevent rigid "middle-down" implementation approaches as local agencies locked onto aspects of the program they anticipated to be monitored. Second, the vigor with which local governments and firms promoted market development shaped residents' motivation and confidence. Third, variable environmental conditions brought correspondingly variable tree establishment and livelihood impacts. Finally, and most critically, residents acted on their experiences and expectations, negotiating implementation to avert perceived risks and seize opportunities. These intersecting processes are locally situated and unpredictable. Together they yield a picture of state environmental policy in China that shows greater responsiveness among policymakers, local officials, and community residents than do prevailing narratives. Even with the compromise of dual-function forests, localized responses brought widely varying outcomes.

\section{RFFP and the Genesis of Dual-Function Forests}

\subsection{The Contours of the Returning Farmland to Forest Program}

Amid alarm at global forest loss, recent decades have brought surprising reversals, as the pace of rainforest loss has diminished and novel forests have emerged on deforested land across the global South (Chazdon, 2008; Lugo, 2009; Rudel et al., 2005). These forests are diverse, shaped by state agricultural and land-use policies, changing commodity markets, urbanization processes, social movement campaigns, and the choices and perceptions of rural households (Hecht, 2011; Lambin and Meyfroidt, 2010; Meyfroidt and Lambin, 2011). Emerging forests are often in inhabited areas and are often used by residents as sources of fuel, timber, fodder, food, and marketable products. The forests may be commercial plantations, agroforestry systems, or spontaneous regrowth on abandoned farmland, and they take shape through processes ranging from compulsory afforestation programs to payments for ecosystem services programs to unprompted household and community responses to changing market conditions or perceived ecosystem degradation.

China has played a major part in this story, and the RFFP is at the center of its forest resurgence. Of China's major forestry programs, it is largest in area covered, fiscal commitment, and number of households affected (Yin and Yin, 2010). The RFFP was initiated after major floods in 
the mid-Yangtze region in 1998, attributed in part to increased sediment transport caused by excessive deforestation upstream. The floods spurred national leaders to undertake an ambitious program of tree planting aimed at curbing soil erosion and desertification. Later, enhancing biodiversity and sequestering carbon were added to the program's mandate (State Forestry Administration, 2014). The RFFP was piloted in the provinces of Sichuan, Gansu, and Shaanxi starting in 1999, and by 2002 it was expanded to 25 province-level jurisdictions. This program is a successor to decades of tree-planting campaigns, but it exceeds all of its predecessors in scale, time span, and fiscal commitment.

The core of RFFP policy is the compensated plantation of trees by rural residents on retired farmland and other uncultivated land. In areas prone to soil erosion, farmers are to retire farmland on steep slopes. Local forestry agencies provide seedlings and technical support for planting trees on retired areas. For each unit of farmland afforested, an equal or greater area of uncultivated land must also be afforested. Afforested areas are defined as "ecological forests" or "commercial forests." Ecological forests have a primary purpose of restoring environmental functions, particularly controlling soil erosion and desertification. Commercial forests provide products that can be marketed, earning income for participating residents, and may provide environmental services to a lesser degree (State Council, 2002). Within a given county, no less than $80 \%$ of the area afforested must be planted in ecological forests (ibid., Article 23).

Compensation is based on the category of planted forest. Households in drier, less densely cultivated northern areas receive a lower level of compensation per unit area than in moist, dense southern areas. Initially this compensation was delivered in grain, but starting in 2005, grain subsidies were replaced with cash payments of 140 yuan per mu (15 mu equal $1 \mathrm{ha}$ ) in the north and 210 yuan per $m u$ in the south. Compensation was to be delivered annually, for a period of eight years for ecological forests and five years for commercial forests. In a given year, compensation is to be delivered only after the local forestry agency has inspected the household's afforested areas and confirmed that they meet stipulated survival rates.

Provisions for participating households do not end with compensation. In addition, households' management rights to the land they have afforested are to be extended for seventy years, and households are permitted to rent or lease out afforested land. At the end of the compensation period, households are permitted to harvest timber. Local governments are also responsible for several types of development initiatives, including promoting decentralized energy technologies; supporting pioneering enterprises and developing new productive sectors to raise incomes and encourage migration to towns; implementing "ecological migration," the resettlement of people living under especially harsh environmental conditions; and promoting enclosed livestock husbandry while forbidding grazing in forests (ibid., Articles 50-56).

In the first years of the RFFP, however, problems arose with implementation, and major changes were made in 2003 and 2004. Seeing subsidies as a potential boon for development, and often a chance to siphon funds, local governments vied for afforestation quotas, frequently authorizing the afforestation of large areas before plans had been approved (State Forestry Administration, 2006; $\mathrm{Xu}$ and Cao, 2002). Grain surpluses used for subsidies dwindled, raising concerns both about the sustainability of subsidies and about grain security goals (Xu et al., 2006). Among other changes, central authorities substituted cash payments for grain deliveries, reduced central fiscal commitments, and scaled down plans for further retirement of cropland 
(ibid.; Yin and Yin, 2010). Official statements indicated a move from expanding the program to consolidating its achievements, (State Forestry Administration, 2004; Yunnan Office of Western Development et al., 2004).

As eight-year subsidy periods began coming to term in 2007, the State Council prolonged RFFP subsidies for another 8- or 5-year period, at reduced rates of 125 yuan per $m u$ per year in the south and 90 in the north. It curtailed further retirement of cropland but decreed continued support for auxiliary measures and fiscal support to RFFP areas (State Council, 2007). While the initial purpose of RFFP was to curb environmental degradation, its focus shifted to rural development and poverty alleviation.

\subsection{Fundamental Tensions, Heterogeneous Responses}

The RFFP thus embodies several kinds of trade-offs. The first involves environmental goals and development goals. While policy statements invariably emphasize "ecology first" (shengtai youxian), this objective is often difficult to reconcile with social and economic goals. Afforestation of cultivated land to provide ecosystem services may place further constraints on already poor farmers who cultivate marginal lands. Allowing large areas of intensively managed, economically productive forests might diminish burdens on rural residents but would compromise ecological objectives (Zhai et al., 2013). This tension is central to almost all evaluations of the RFFP.

A corollary tension arises from contrasting principles of implementation. The RFFP sets out environmental criteria for inclusion: serious soil erosion, desertification, or salinization alongside low and unstable grain productivity (State Council, 2002, Article 15). Slope often acts as a proxy for environmental criteria, with policy calling for afforestation of farmland on slopes greater than 15 degrees in the north and 25 degrees in the south. RFFP regulations also prioritize voluntary participation (ibid., Article 5), yet there is no clear provision for situations in which rural households are unwilling to afforest land that meets policy criteria. Thus local officials are charged with reconciling environmental criteria, the formal requirement of voluntary participation, and the practicalities of implementation. They have sometimes applied additional criteria, including prioritizing contiguous areas and areas near roads, which are simpler to plant, manage, and monitor ( $\mathrm{Xu}$ and Cao, 2002).

These tensions lead to diverse outcomes. Studies show sharp differences in the proportion of farmland afforested (Caldwell, et al., 2007; Song, et al., 2014; Zhao, et al., 2004), tree survival rates (Bennett, 2008), forest cover gains and losses (Li, et al., 2013), the extent to which participation is actually voluntary (Bennett, 2008; Xu, et al., 2010), impacts on off-farm labor (Groom, et al., 2010; Kelly and Huo, 2013b), and whether RFFP brings net economic gains or losses (Bennett, 2008; Xu, et al., 2010; Yin, et al., 2014). Larger-scale studies tend to find successful afforestation (e.g. Lü et al., 2012; Zhou et al., 2012), while small-scale field-based studies most frequently uncover discrepancies between formal policy and on-the-ground outcomes (e.g. Cao et al., 2009; Ediger, 2008; He and Lang, 2015; Trac et al., 2007, 2013). Geographic variation is also important: Provinces have taken varying approaches to implementing the RFFP (Bennett, 2008), but sharp differences in outcomes also occur across neighboring townships and counties (ibid.; Caldwell, et al., 2007, Trac et al. 2007, Weidner, 2013). It is thus difficult to find patterns or make robust generalizations about local results. 
It might be tempting to consider the RFFP to be just another instance of local distortion of central policies in China (O'Brien and Li, 1999; Smith, 2013, Yin et al., 2013). Yet local studies show much more going on. Depending on pressures from above or from below, local officials have taken starkly different approaches. Implementing RFFP placed great demands on time and personnel of county and township forestry agencies and village governments (Bennett, 2008; Bullock and King, 2011). Moreover, these officials were faced with the challenge of explaining to often impoverished farmers why they must relinquish farmland that was the foundation of their subsistence. In some places, participation by residents is largely involuntary (ibid.; Ediger, 2008; Trac, et al., 2007); in others, officials have stressed broader concerns of residents. In selecting RFFP sites, forestry departments may favor communities whose leaders have strong government connections (Xu et al., 2010). Local governments may prioritize maximizing household participation over conformity to ecological criteria, spreading out benefits and limiting conflicts (Trac et al., 2013; Weidner, 2013). In turn, residents experience and respond to the program differently.

A second issue concerns the nature of the planted forests. Whether lauding or criticizing this move, much of the literature agrees that the RFFP's primary emphasis is on establishing reforestation areas as spaces of environmental rehabilitation, where residents' activities are severely limited. Where afforestation burdens residents, it is often attributed to an emphasis on ecological forests (Grosjean and Kontoleon, 2009; Wang and Maclaren, 2012); where it does not achieve environmental goals, it is often attributed to inadequate establishment of natural forests (Zhai et al., 2013). Yet close examination reveals that rather than focusing exclusively on environmental restoration, policymakers modified the program to accommodate both social and environmental concerns. Local officials and residents implemented afforestation in ways that reflected this change, giving the RFFP a potential role in maintaining land-based livelihoods, even as its rhetoric continued to stress all-out environmental restoration.

\subsection{Dual-Function Forests}

Dual-function forests reveal a key move aimed at reconciling the tensions the RFFP raises. The Classification Standards for Ecological Forests and Commercial Forests under the Returning Farmland to Forest Program, issued by the State Forestry Administration in 2002, contained lists of tree species designated for ecological and commercial forests respectively, as well as "dual-function species that have a primary aim of environmental results" (yi shengtai xiaoyi wei zhuyao mubiao de jianyong shuzhong). A pair of lists, applying respectively to northern and southern regions of the country, includes a wide range of species, such as tea, mulberry, walnut, persimmon, and tea oil (Table 1.).

A State Forestry Administration official who had overseen RFFP from its initiation explained,

In the course of returning farmland to forest, in order to allow farmers to pass inspections, we designated ecological and commercial dual-function species. As long as ecological measures, program measures, and agricultural measures are well integrated, these species can obtain ecological results as well as economic results. It is a win-win policy. (China Net, 2007)

This compromise revolutionized the program's potential implications for residents and for landscapes. 
Table 1. Listing of Dual-Function Species

\begin{tabular}{|c|c|}
\hline Region & Species \\
\hline North & $\begin{array}{l}\text { 黑核桃 Juglans nigra (black walnut), 核桃 Juglans spp. (walnut)、板栗 Castanea spp. } \\
\text { (chestnut), 菄树 Ziziphus jujuba (jujube), 柿树 Diospyros kaki (persimmon), 山杏 Prunus } \\
\text { armeniaca (apricot), 山楂 Crataegus pinnatifida (Chinese hawthorn), 桑树 Morus alba } \\
\text { (mulberry), 花椒 Zanthoxylum spp. (Sichuan pepper), 枸杞 Lycium barbarum (goji or } \\
\text { boxthorn), 杜仲 Eucommia ulmoides (hardy rubber tree), 漆树 Toxicodendron vernicifluum } \\
\text { (lacquer tree), 油橄榄 Olea europaea (olive), 乌柏 Triadica sebifera (Chinese tallow tree), 油桐 } \\
\text { Vernicia fordii (tung oil tree), 山茱莫 Cornus officinalis (cornelian cherry) }\end{array}$ \\
\hline South & $\begin{array}{l}\text { 油茶 Camellia oleifera (tea oil camellia), 核桃 Juglans spp. (walnut), 油橄榄 Olea europaea } \\
\text { (olive), 乌柏 Triadica sebifera (Chinese tallow tree), 板栗 Castanea spp. (chestnut), 束树 } \\
\text { Ziziphus jujuba (jujube), 柿树 Diospyros kaki (persimmon), 木瓜 Pseudocydonia sinensis } \\
\text { (Chinese quince), 木豆 Cajanus cajan (pigeon pea), 任豆 Zenia insignis, 茶树 Camellia sinensis } \\
\text { (tea), 桑树 Morus alba (mulberry)、漆树 Toxicodendron vernicifluum (lacquer tree), 花椒 } \\
\text { Zanthoxylum spp. (Sichuan pepper), 杜仲 Eucommia ulmoides, 厚朴 Magnolia officinalis } \\
\text { (houpu magnolia), 山荣莫 Cornus officinalis (cornelian cherry), 山核桃 Carya cathayensis } \\
\text { (hickory), 香榧 Torreya grandis (Chinese nutmeg tree), 油桐 Vernicia fordii (tung oil tree) }\end{array}$ \\
\hline
\end{tabular}

Notation: Chinese common name, Latin notation, (English common name).

Source: State Forestry Administration, 2002

Nationwide statistics on the extent of dual-function forests are not publicly available, but provincial reports suggest that they amount to as much as one-third of the area planted under RFFP: $30.6 \%$ in Yunnan (Long, 2008), 32.7\% in Shaanxi (Zhang and Xue, 2007), and in Jiangxi, over $60 \%$ in a single dual-function species, oil camellia (Liu et al., 2008). Case studies and anecdotal evidence suggest similar prevalence in other provinces (Mu and Liu, 2010; Trac et al., 2013; Weidner, 2013; Zhen et al., 2014).

Dual-function forests provide a useful lens for understanding both the flexibility of the policy and how local interactions have conditioned RFFP implementation. The case studies that follow show different ways residents and local officials have engaged the RFFP in locales where dualfunction forests are predominant.

\section{Cases}

\subsection{Weixi County, Yunnan}

In Weixi Lisu Nationality Autonomous County in the northwestern part of Yunnan, mountains reaching over 4,000 $\mathrm{m}$ in elevation slope down to river valleys below 1,700 $\mathrm{m}$ (Fig. 1).

Monoethnic Lisu communities predominate at higher elevations, while riverside communities are of Naxi, Han, Bai, Lisu, or mixed ethnicity. According to county forestry bureau officials, 3,900 ha of farmland and 3,700 ha of uncultivated land were afforested in Weixi under RFFP. In summer and fall 2014, [Author 1] conducted fieldwork in five communities that had undertaken RFFP, within three administrative villages in two neighboring townships. Fieldwork included a questionnaire survey on livelihoods; focus groups on forest use and change; forest quadrat 
measurements; and intensive interviews with community leaders and forest stewards, selected residents, and forestry personnel.

\section{[FIGURE 1 ABOUT HERE]}

Fig. 1. Location of study sites in the People's Republic of China.

Nearly all RFFP forests in Weixi are dual-function forests. From the start of implementation in 2002, RFFP forests were planted primarily with walnut or Chinese quince (Pseudocydonia sinensis), often together with chestnut, Sichuan pepper, and qingciguo (Prinsepia utilis). All are classified as ecological forests. County officials promoted these varieties within a broader strategy of planting economically valuable species as ecological forests throughout Yunnan (Li, 2004). County forestry officials assert that these varieties meet both the requirements for ecological effectiveness and the income needs of poor rural residents.

Yet most afforestation plots did poorly. Year after year residents had to replant walnut trees, with seedlings sometimes provided by the county Forestry Bureau but more often scavenged from community forests. Where qingciguo and Sichuan pepper were planted in the understory, sometimes these plants simply died, or else residents actively removed them. Residents often had little interest in RFFP forests. While residents appreciated receiving cash subsidies, RFFP forests themselves offered little direct benefit as long as walnut trees did not bear fruit. In some instances, livestock grazing, formally banned in RFFP areas, damaged seedlings. In others, local soil and hydrological conditions impeded walnut tree establishment.

In the community of Dadahei, ${ }^{1}$ Rong, who had become influential through his success in business, helped to secure access to RFFP for the community and facilitated modifying implementation methods to suit his fellow villagers. Initially, while residents of many communities were skeptical of the program, Rong pushed to get Dadahei included in RFFP. While a lack of available uncultivated land led most communities in the area to count farmland afforested under RFFP as half farmland and half uncultivated "wasteland," thus receiving subsidy for only half the farmland retired, Rong was able to get a fallow area that had once been a collective medicinal cultivation area designated for uncultivated land afforestation. Dadahei became the only community in its administrative village to implement RFFP, and Rong served as the forest steward in charge of implementing RFFP there.

Dadahei community leaders also responded to township forestry authorities' priority on retiring contiguous areas. Aiming to ease management and boost environmental benefits, township forestry authorities designated a swathe of steep land above the village for retirement. Because not all households had farmland in that area, several would not have access to the program. Community leaders pushed to include a second band of farmland, below the settlement. After some pushing, forestry authorities consented. As a result, more community members could access the program, while households that did not want to participate were still allowed to opt out. In contrast, in Tsuza community in the same township, community members who wanted to participate but did not have land in the planned afforestation area were excluded, and community leaders did not mobilize to change RFFP implementation.

${ }^{1}$ All names of persons and communities in Weixi are pseudonyms. 
Although afforestation brought subsidies to most households in Dadahei while allowing them to reduce their workloads on the community's poorest land, the trees grew poorly. Forestry authorities threatened to withhold RFFP subsidies. Community members broached the idea of switching to pine on patches where walnut trees were failing. Rong took the idea to township and county forestry agencies and won approval, then organized community members to plant pine seedlings gathered in community forests. On a sizable portion of their RFFP land, Dadahei residents have abandoned dual forests, and pine forests are emerging. On the rest, walnut trees stand, but after more than a decade few bear fruit.

In Achi Village, a tree-planting enthusiast catalyzed successful walnut cultivation. In the 1980s and 1990s, well before RFFP was initiated, areas of several communities in Achi had been designated "nut production bases," where households converted grain fields into walnut groves. Wanting to improve his trees, Hui took an interest in grafting. He asked and read about techniques and experimented in his grove. As he honed his craft, he began helping neighbors graft their trees. By the time RFFP took place, he was appreciated across the village for making his own and others' trees - walnut, plum, persimmon, and more-bear more fruit.

When RFFP commenced, residents were required to plant extremely dense walnut stands -133 stems per $m u$-and prohibited from planting crops amid the seedlings. Unlike in the township to which Dadahei belongs, RFFP plots were scattered, because households were allowed to decide which plots to afforest. Still, Hui recounted,

These eager officials, all they thought about was restoring tree cover, the environment - they weren't thinking about the impacts on farmers, the economic impacts. We did it for four or five years, and it was just a mess. Weeds grew up around the seedlings, and the walnuts couldn't survive.

Knowing it would help the seedlings grow, Hui planted a leguminous green fertilizer crop in his RFFP plot. Forestry officials sanctioned him; they ordered him to dig up the crop. "I said, if ten years from now, you come and see, if I don't succeed, I will pay back the subsidy seven times over. Ten years later, on each $m u$ they gave 260 yuan for, I can make over a thousand yuan each year." Before the 2007 extension of RFFP made intercropping official policy, local forestry authorities had begun to relent, allowing weeding and intercropping in RFFP plots. Hui was chosen as forest steward for Achi, responsible for monitoring standing forests and RFFP plots.

Cultivating dual-function forests posed pointed challenges. Forestry officials confronted tensions between the environmental goal of growing closed-canopy forests and rural development aims like cultivating productive walnut trees. The methods of planting walnut trees that local authorities initially used fostered neither of these goals. While these areas have a long history of walnut cultivation, with giant walnut trees over a century old dotting the landscape, walnuts planted under RFFP often languished. Residents, forbidden from doing activities with short-term benefits on RFFP plots, saw little reason to tend them. Only where residents worked to modify the program did it turn out in ways that suited them better. Doing this depended on having activist residents who could access authorities to secure modifications.

The impacts of RFFP in Weixi have been environmentally and socially heterogeneous. Within a fifty-kilometer stretch, plantations range from bare slopes dotted with straggling juvenile 
walnut trees, to groves with grazed understories, to emerging pine forests (Fig. 2). Sichuan pepper and qingciguo are nearly absent. Yet a new generation of walnut trees, planted after 2008, outside of the RFFP, has met widespread acceptance. This time, instead of ceasing to grow ground crops when trees are planted, people were encouraged to plant field crops amid seedlings. Fertilization and protection from grazing due to the crops beneath them have helped these trees fare better. Although many walnut groves planted under RFFP fare poorly, benefits from the trees that have matured have primed people for large-scale cultivation of walnuts.

\section{[FIGURE 2 ABOUT HERE]}

Fig. 2. RFFP plantations in Weixi: (a) walnuts overtaken by native vegetation; (b) heavily grazed and repeatedly replanted walnut plantation. Both plantations are 11 years old and on southfacing slopes above $2000 \mathrm{~m}$ (photographs by [Author 1]).

\subsection{Sanjiang, Wenchuan, Sichuan}

Sanjiang Township is situated in the Qionglai Mountain Range in western Sichuan, approximately $50 \mathrm{~km}$ west of Dujiangyan, at elevations between 1200 and $3500 \mathrm{~m}$. Its mountainous landscape is extensively forested, rich in biodiversity and endemism. Sanjiang is a part of the Aba (Ngawa) Tibetan and Qiang Autonomous Prefecture. In 2007, the township had a population of 4000, most of which was ethnic Tibetan or Han. More than 90 percent are farmers.

This case study looks at one of Sanjiang's nine administrative villages, Caoxiu, ${ }^{2}$ site of an ethnographic study on rural energy development as a tool for forest conservation. [Author 2]'s fieldwork involved village-wide household surveys, semi-structured interviews, and extensive participant observation over a six-month period in 2009. At the time of research, there were 86 households, ${ }^{3}$ nearly all of whose main economic activity was agriculture - farming and animal husbandry. Forest resources were also significant for subsistence and as sources for cash income. Some households received off-farm income from migratory work, although this was not widespread.

The RFFP program was introduced in Caoxiu in 2003. All households with farmland participated in the program; on average, households retired $5.4 \mathrm{mu}$ of farmland and retained 5 $m u$ as farmland. Households were granted direct control over the location and extent of land area on which to carry out the program. These households have also demonstrated control over the kind of trees planted.

When the program started, the local government gave households seedlings of kudingcha (Ilex latifolia), a kind of holly tree whose leaves are commonly dried and sold in the tea market.. Although kudingcha does grow in the region, households across the village experienced low survival rates with their plantings. That, combined with the product's low market value, led to the complete replacement of kudingcha early on in the program. Collectively, households in Caoxiu purchased and planted houpu (Magnolia officinalis) to replace kudingcha trees and to continue participation in RFFP. Houpu, a magnolia valued for its medicinal bark, is harvested only after 15 years of growth, a much longer return period than kudingcha, whose annual harvest of leaves can provide cash annually. But in addition to survival rate concerns,

\footnotetext{
2 Pseudonym used for the village.

${ }^{3}$ By official hukou records, there are 121 households in Caoxiu. This research examines households as units that live, eat, and work together; and contribute and withdraw from a common savings.
} 
households preferred houpu for its higher and more stable market value. In 2009, stands of established houpu were widely visible throughout the village.

By reducing the area of farmland cultivated, the RFFP directly reduced the time and labor needed for farmland cultivation. However, households in Caoxiu did not necessarily respond by shifting labor off-farm or adopting alternative livelihood activities. In Caoxiu, forests and forest resources remain an important source for subsistence and cash income. In surrounding state forestlands, households graze livestock, hunt wildlife, collect fuel wood, and harvest timber and non-timber forest products such as medicinal plants. While forest activities may absorb labor freed from farming, time and labor availability do not simply determine the extent and kind of engagement in forest activities. Several villagers described how they used to regularly collect medicinal plants in the forests but have stopped since the 2008 earthquake, which triggered landslides burying the medicinal roots and blocking this valuable source of income for many households. Rural development following the earthquake, however, established a more extensive road system into the village that made it easier to engage in illegal timber harvest and trafficking.

All farmlands afforested in Caoxiu are dual-function forests, formally classified as ecological forests. To residents, the houpu plantations were indeed part-ecological and part-commercial. They recognize the potential value of houpu as a cash crop, and many households planted the species voluntarily along trails and roads and in between fields, a practice that has continued outside of the RFFP. While acknowledging the economic value of houpu plantations, residents were emphatic that these were ecological forests. Residents often explained that houpu plantations are ecological by comparison to the maize cultivation that preceded them. However, they acknowledged that the ecological value of these RFFP lands were not comparable to those of surrounding natural forests, or even the fir plantations cultivated in the 1980s. The classification of houpu as ecological was important to residents because houpu didn't offer immediate income. They argued that RFFP plantations merited, and depended on, the 8 years of compensation. Further, residents asserted the need for continued compensation because houpu takes fifteen years to become harvestable. What will happen to these lands after houpu is harvested is unclear. Residents expressed that whether they might replant with ground crops would depend on the profitability of houpu.

By 2009, the implementation of RFFP in Caoxiu had produced successful cultivation of houpu forests on former cropland (Fig. 3). While RFFP implementation in the village did not explicitly target marginal or contiguous cropland, village-wide engagement did result in considerable conversion of land area overall, and it is probably reasonable to assume that households retired their least productive lands (Kelly and Huo, 2013a). Furthermore, the removal of tillage agriculture is likely to reduce soil loss. Still, with households uncertain about keeping farmland retired, long-term ecological benefits are not secure.

[FIGURE 3 ABOUT HERE]

Fig. 3. RFFP sites in Caoxiu: (a) houpu planted on sloped land; (b) cropland, houpu plantation, and fir forest (photographs by [Author 2]).

In contrast, the program's economic benefits are clear. Village-wide engagement ensured that all households in Caoxiu received program subsidies, while the dual-function forest 
classification entitled households to receive compensation for the longest possible period. Residents have enjoyed the compensation for houpu, which has required little effort to maintain. Further, labor freed from farm work has allowed them to take advantage of different activities. Still, some of these activities may have environmentally destructive impacts, and there is a general lack of alternative livelihood opportunities. This raises questions about the capacity of RFFP to produce not just short-term but also long-term socio-economic benefits.

With conversion from row crops to tree plantations, households no longer work these retired lands the same way, but the land is still expected to be economically productive at the same rate as before. While defining dual-function forests as ecological forests underlies claims of delivering environmental benefits, this case illustrates short-term achievements and uncertain long-term potential shaped by economic factors and ambiguous environmental efforts.

\subsection{Baiwu Township, Yanyuan County, Sichuan}

Baiwu Township encompasses a river basin and the surrounding foothills, along with part of the Zala Mountains, in the central part of Yanyuan County, Liangshan Yi Autonomous Prefecture, in southern Sichuan near the Yunnan border. Elevations range from 2400 to 3800 meters. Among Baiwu's eight administrative villages, Baiwu, Changma, and Mianba have the largest amount of forested land, and research by [Author 2] and [Author 4] has concentrated in this area. In 2010, Baiwu's population of 20,038 was $92 \%$ Nuosu, classified as Yi, with the remainder mostly Prmi (classified as Zang, or "Tibetan" in Sichuan) and Han. At the time of our initial research in the early 2000s, almost all inhabitants were subsistence farmers, herders, and foresters. In the last decade, off-farm income from migratory labor has become more and more important (Harrell and Aga, 2013), but almost all resident households still grow maize, potatoes, and buckwheat for subsistence, along with Sichuan peppers and walnuts as cash crops. Many still herd cattle and water buffaloes, and a diminishing number have flocks of several tens of sheep and goats; most people keep pigs, though decreasing numbers of families let their pigs out to graze with the other animals. People still obtain a majority of their heating and cooking fuel from local forests and use wood to build houses and make tools.

Between the Democratic Reforms in $1957^{4}$ and the mid-1990s, deforestation was severe. This caused sediment accumulation in the river valleys, which in turn resulted in changes in river courses and increased flashiness and flooding (Urgenson et al., 2010). With the first forest reforms of the Reform and Opening Era in 1983, however, the tide began to turn. At that time, local forests were divided into state forests, closed to logging and wood collection except by permit; collective forest, where local families could collect fuel freely and cut trees by permit, and a small area of privately contracted forests, which individual contracting households could manage as they saw fit.

Three households who contracted private forests were the first to attempt reforestation, setting aside the little hilltops they had contracted, asking others not to cut trees there, and occasionally planting seedlings of native Pinus yunnanensis. Other local experiments with pines produced

\footnotetext{
${ }^{4}$ In most areas of the Southwest with primarily Ethnic Minority (shaoshu minzu) population, the Land Reform of 1947-51 was not carried out; local social and economic structures remained in place until 195657, when local leadership was replaced by party-appointed cadres and local systems of land tenure were replaced with agricultural collectives. This process was called the Democratic Reform (minzhu gaige).
} 
some forest growth on previously farmed hillsides, but systematic reforestation began in 1998, when villagers in Baiwu and Mianba Administrative Villages were given seedlings of two exotic species, Robinia pseudoacacia and Prinsepia utilis, to plant on uncultivated "wastelands" under the Natural Forest Protection Program. In 2006, [Author 2] surveyed eight sites where these trees were planted, and found most of them to be bare, while in the others a few trees struggled to survive; they were gone by 2012.

In Changma Administrative Village, RFFP plantations that began in 2003 had similarly dismal results, even though they used commercial species. Three sites were planted with the aforementioned qingciguo (Prinsepia utilis), and two with species that had long been grown, and are still grown in the area, walnut (Juglans regia) and Sichuan pepper (Zanthoxylem piperitum). The walnut and pepper plantations had failed by the time of [Author 2]'s investigation in 2006; the qingciguo was struggling. Since walnuts and Sichuan peppers usually grow well in the area, we need to look for other reasons why they failed. It is possible that the microenvironments were unsuitable-perhaps that is why these species were not planted in those locations beforeor that farmers who reported not receiving compensation did not take care of the trees, or perhaps herders grazed their animals indiscriminately in the plantations. Author 2 talked to one farmer who, angered at receiving no compensation for the land he took out of production, intentionally neglected the plantations and even sabotaged tree growth by allowing his animals to graze on the newly planted trees. Either way, reports from the Baiwu Township government to the Yanyuan County forest bureau showed that all RFFP plantings in the entire Township met the RFFP standard of $85 \%$ seedling survival.

Ironically, a partially successful reforestation effort took place outside the RFFP. Starting in 2008, a retired Yanyuan county official and native of Baiwu village obtained funds to plant sections of the river terraces and alluvial fans in the Apiladda valley, ravaged by erosion and hydrological shifts beginning in the 1980s, with fast-growing poplar (Populus), which was intended to stabilize the river banks in a few years and provide fuel and income after 15 years or so. Despite efforts to fence in the plantations, free-ranging pigs rooted out some of the trees, so that only about half survived. Beginning the following year, village families began to plant buckwheat, maize, and string beans on some of the fans and terraces, and in 2010 replaced some of the failed poplars with walnuts, interplanting with maize. However, by 2014 most of the walnut trees had died, though the poplars that had survived the initial porcine onslaught were two to three meters high and flourishing.

The attempt to fence off the plantations from livestock did not sit well with some of the local families who had large flocks of sheep, however. Despite promises that the plantations only needed to be fenced and off-limits to the flocks for three years, shepherds wondered where the sheep would graze in the meantime. As it turned out, between 2009 and 2012 many families sold their entire flocks, primarily because there was no one left to herd them, so that there was sufficient pasture for the remaining flocks after all. Beginning in about 2014, a few families reacquired sheep and goats, which they could graze in plantations without endangering the now 6 centimeter or thicker trees.

Results of RFFP and related reforestation efforts in Baiwu have thus been every bit as heterogeneous as those in Achi and Dadahei (Fig. 4). While almost all the RFFP efforts have involved commercial species, and are thus classifiable as dual forests, some have succeeded and 
others have failed. Not only this, but different villagers, with different stakes in the outcome, have greeted the efforts differently. Some have participated enthusiastically; some-particularly those whose livestock lost access to favored pastures - have groused; and perhaps some have sabotaged, though this is difficult to prove. Whatever the actual outcome on the ground, local officials have reported the programs as successful, thus contributing to the reported success of the national RFFP program, whatever the results locally.

\section{[FIGURE 4 ABOUT HERE]}

Fig. 4. RFFP sites in Baiwu: (a) Rows of holes where trees were planted are the only trace in 2012 of an unsuccessful Prinsepia utilis plantation from 2004. (b) Poplars planted at local initiative to stabilize river terraces in 2008 are growing, but have not had their desired anti-erosion effect (photographs by [Author 4]).

\subsection{Wuzhishan Municipality, Hainan}

In other locales, commercial plantations contracted to silviculture firms have played a central role. One such place is Wuzhishan, a county-level municipality (xianjishi) in the interior of the island province of Hainan in China's far south. Occupying Hainan's central mountains, Wuzhishan ranges from $69 \mathrm{~m}$ to 1,860 $\mathrm{m}$ in elevation. Most of its 107,000 residents are of Miao or Li ethnicity. In 2005, approximately $51.7 \%$ of its area was under natural forest cover, with another $34.8 \%$ under anthropogenic forest and tree plantations. Our discussion of Wuzhishan draws from research conducted by [Author 3] and colleagues, drawing from published (Zhai et al., 2012; Zhai et al., 2013) as well as unpublished findings.

Official records state that in Wuzhishan between 2000 and 2005, 102,500 mu (6833 ha) were afforested under RFFP. Of this figure, 95\% were designated ecological forests and the remaining $5 \%$ commercial forests ( $\mathrm{Wu}$ and $\mathrm{Li}, 2007)$. Virtually all of the ecological forests are dual-function forests.

While the RFFP is usually thought of as centered on smallholders, rural households are only one of four kinds of entities charged with afforestation in Wuzhishan, and they manage less than one-third of RFFP forests. Nearly $70 \%$ of afforestation area is contracted to outside investors. The largest single holder of RFFP land is Jinhua Company, a subsidiary of Sinar Mas Group, the Indonesia-based conglomerate that owns Asia Pulp and Paper. Jinhua manages 24\% of RFFP land in Wuzhishan. Holdings of five other companies make up an additional 28\%, and thirty smaller investors together account for another $17 \%$. These owners are primarily responsible for afforesting uncultivated land rather than retired cropland. They contract rights to forest land from village committees, taking on responsibility to afforest non-agricultural land that at the time did not have a closed canopy. In some cases, lands that the companies had contracted and planted prior to the program's initiation were grandfathered into the RFFP.

Different categories of owners have planted different tree varieties. Jinhua's holdings are exclusively eucalyptus and acacia plantations that supply the company's pulp mills. Of forest area controlled by the five smaller companies, $88 \%$ is in high-value timber species (basswood [Eudospermum Chinese], redwoods [Dalbergia odorifera and Dalbergia hainanensis], Chinese eaglewood [Aquilaria sinensis], yellow cheesewood [Nauclea sp.], and rattan [Daemonorops margaritae, Calamus simplicifolius]), with the remainder in eucalyptus and acacia. Holdings of 
smaller investors are more varied, with 59\% in monocrop pine (Pinus caribaea) plantations, $14 \%$ in fruit orchards (primarily coconut [Cocos nucifera], areca nut [Areca catechu], mango [Mangifera indica], longan [Euphoria longana], and lychee [Litchi chinensis]), 13\% in pulp species, $8 \%$ in highvalue timber, and 5\% in rubber. Among forests managed by smallholders, rubber (45\%), fruit $(21 \%)$, and pine $(19 \%)$ plantations predominate, with smaller areas in timber $(13 \%)$ and pulp species (3\%) (Zhai et al., 2013). As the size of the holding decreases, plantation content shifts from pulp and timber to fruit and rubber (Fig. 5).

\section{[FIGURE 5 ABOUT HERE]}

Fig. 5. Wuzhishan tree plantations: (a) Eucalyptus managed by Jinhua company; (b) rubber managed by smallholders (photographs by [Author 3]).

Fruit and rubber plantations earn Wuzhishan households a good deal of money, and residents are inclined to maintain their forest plantations. The threat of converting afforested areas back to farmland is nearly absent. [Author 3's] 2007 survey of 300 households in ten communities within three townships found that for nearly two-thirds of households, rubber accounts for over $70 \%$ of household income. Eighty percent indicated that they plan to maintain afforested areas in the current tree species after RFFP subsidies discontinue. For most, income from fruit or rubber makes the difference. The $13 \%$ who have leased afforestation land to Jinhua have no choice in the matter, however, as Jinhua determines management for the thirty-year term of the lease. Afforestation subsidies may have been a crucial supplement after households retired ground crops and before rubber and fruit trees began to produce. However, the economic returns to cash crop tree species now render RFFP subsidies irrelevant to maintaining tree cover.

The RFFP in Wuzhishan is an unquestionable success for the rural economic growth projects of local governments, but from the perspective of the environmental objectives of the RFFP, the outcome is ambiguous at best. While total forest cover has increased, rubber and pulp plantations have displaced indigenous forest (Zhai et al., 2012), a trend that has been found in other areas of southern Mainland China as well (Li et al., 2007; Sturgeon, 2010). These plantations can provide certain ecosystem services, but not as well as intact forests ( $\mathrm{Li}$ et al., 2007; Zhai et al., 2012). Hainan's RFFP forests are part of an expansion of pulp plantations that is fragmenting the habitat of the Hainan gibbon (Greenpeace China, 2011). The environmental consequences of afforesting uncultivated land are also problematic. The afforestation of shrubland and grassy areas neglects the possibility that these areas might be in early stages of regenerating to natural forest and, even if this is not the case, may underestimate the ecological value of ecosystems that are not closed-canopy forests (Zhai et al., 2013). In these tropical areas, the tensions between environmental and economic promises of the RFFP are particularly acute. 
Table 2. Central-level policy making and local implementation processes

\begin{tabular}{|c|c|c|c|c|c|}
\hline \multicolumn{2}{|l|}{ Location } & Weixi & Baiwu & Sanjiang & Wuzhishan \\
\hline \multicolumn{2}{|c|}{ Primary plantation trees } & $\begin{array}{l}\text { walnut, Sichuan } \\
\text { pepper, qingciguo, } \\
\text { pine }\end{array}$ & $\begin{array}{l}\text { Robinia, } \\
\text { qingciguo, pine, } \\
\text { poplar, walnut }\end{array}$ & $\begin{array}{l}\text { kudingcha, } \\
\text { houpu }\end{array}$ & $\begin{array}{l}\text { rubber, eucalyptus, } \\
\text { acacia, basswood, } \\
\text { pine, others }\end{array}$ \\
\hline \multicolumn{6}{|l|}{ Forest categorization } \\
\hline \multirow[t]{3}{*}{ Forest types } & Commercial & & & & $x$ \\
\hline & \begin{tabular}{|l|} 
Ecological \\
\end{tabular} & $x$ & $x$ & $x$ & $x$ \\
\hline & ${ }^{*}$ Dual-function & $x$ & $x$ & $x$ & $x$ \\
\hline \multicolumn{6}{|l|}{ Implementation } \\
\hline \multirow{3}{*}{$\begin{array}{l}\text { Implementation } \\
\text { shaped by }\end{array}$} & Local government & $x$ & $x$ & $x$ & $x$ \\
\hline & Residents & $x$ & $x$ & $x$ & \\
\hline & Outside investors & & & & $x$ \\
\hline \multirow{2}{*}{$\begin{array}{l}\text { Planting took place } \\
\text { on }\end{array}$} & Uncultivated Land & $x$ & $x$ & & $x$ \\
\hline & Farmland & $x$ & $x$ & $x$ & $x$ \\
\hline \multirow[t]{2}{*}{$\begin{array}{l}\text { Area of cultivation } \\
\text { defined by }\end{array}$} & $\begin{array}{l}\begin{array}{l}\text { Connectivity, cultivation } \\
\text { of contiguous spaces }\end{array} \\
\end{array}$ & $x$ & & & $x$ \\
\hline & $\begin{array}{l}\text { Participation, maximizing } \\
\text { household engagement }\end{array}$ & $x$ & $x$ & $x$ & \\
\hline
\end{tabular}

\section{Discussion}

Dual-function forests upend conventional understandings of the RFFP. They represent a shift from an exclusive focus on environmental outcomes to a mixed focus on environmental and livelihood benefits, a central and often overlooked transition in the history of the program. Neglecting dual-function forests could lead to major errors, not just in evaluating the impacts of the RFFP, but more broadly in understanding environmental governance in China overall.

\subsection{Policy Flexibility and the Performance of Local Officials}

The genesis of dual-function-forests falls within a pattern of initial uniform policy, local adaptation, and consequent central adjustment and compromise as state authorities grope for a synthesis between productivist logics and newly introduced environmental logics. Before 1998, farmland had been governed for the extraction of grain surplus to support urban industrialization, and the state had encouraged the opening and cultivation of even the most marginal lands. The 1998 flood served as a "focusing event" (Rudel, 2013) that brought an environmental logic to the center of land governance. This flood brought a tidal shift, with a "hard" environmental logic requiring erosion control with "natural" forests, temporarily overwhelming productivist efforts to make sloped fields yield exchange value. State authorities redefined marginal croplands as spaces that must be rehabilitated to control erosion, runoff, and siltation.

Clashing with conditions on the ground, this environmentalist tide receded. Residents resisted relinquishing farmland. Local governments bore demands on personnel and threats to revenue. Meanwhile, a new productivist logic was emerging, centered on producing commodities for the market. While in the initial push for the RFFP the state discouraged commercial forests, the rise of commercial silviculture raised the possibility of coupling productivist land use to a softened 
environmental logic. The term "ecological forest" no longer referred exclusively to naturalistic forests, but was reframed to include forests that have some environmental benefits, as perennial tree cover brings far less soil loss than annual tillage. If things worked according to plan, dualfunction forests would also win residents' favor. What resulted was a joining of a marketized productivist logic with a "softened" environmental component. This synthesis, epitomized by dual-function forests, has eased some of the policy's complications but has also brought others to the fore.

This pattern raises questions about the relationship between policy formulation and policy implementation in China. Narratives of conservation programs in China commonly picture rigid programs of an unbending state (Blaikie and Muldavin, 2004; Yeh, 2009). However, in line with several recent studies (Litzinger, 2004; Mertha, 2009; Wang et al., 2013; Zinda, 2014), the cases presented above show flexibility in environmental programs as state agencies respond selectively to rural residents and private sector actors.

We have little direct evidence of the motivations behind these compromises, but the course of the RFFP and other state projects provide clues. While it is clear that the Chinese state remains willing to use coercive measures to change or replace local livelihoods (Tilt, 2014; LoraWainwright, 2013), state authorities are also concerned with containing or preventing social unrest where compromise can circumvent it (Lee and Zhang, 2013; Michelson, 2008). It is particularly noteworthy that many environmental crises and protests are solved by pecuniary compensation (van Rooij et al., 2012), a strategy similar to the extension of compensation in the RFFP to 15 years. In addition, economic growth is still the most important criterion by which local officials' performance is evaluated, so there may have been upward pressure from local officials to be allowed to modify the policy to achieve growth goals (Eaton and Kostka, 2014; Smith, 2013). At the central level too, while central state authorities have clearly increased their stress on environmental protection and rehabilitation, aims of expanding production constrain environmental policy (Robbins and Harrell, 2014; Wandesforde-Smith, Denninger Snyder, and Hart, 2014).

Dual-function forests are not simply the result of a new set of rigid top-down rules that determine a different approach to afforestation. On the contrary, state authorities have tolerated and even facilitated divergent local responses. As a result, outcomes have varied widely. In some locales, such as Weixi and Sanjiang, county and township officials failed to adequately consider the necessary growing conditions for commodity-producing forests, and dual-function forests only became productive when residents took the initiative to modify their management. In other cases, it appears that orchards have been successfully established under this rubric (Zhen et al., 2014). In Hainan, smallholders welcomed profitable fruit orchards and rubber plantations. At the same time, officials colluded with entrepreneurs to establish pulp and timber plantations as dual-function forests.

Some analyses have found that the primary problem with RFFP in the field was divergent implementation by local officials responding to perverse incentives, a general problem with local implementation of policies that goes beyond the RFFP (e.g. Xu and Cao, 2002; Zhai et al., 2013). Perverse incentives are doubtless present, but officials may also respond to local residents' concerns or deal with tradeoffs among competing demands of different policies (e.g., when a commitment to restoring natural forests conflicts with maintaining social stability). These 
actions may be cynical and careerist, or they may be directed toward local economic welfare, ecological preservation, supporting members of kin and social networks, or some combination of these.

What such actions have in common is the element of performance. Performance is an important requirement for bureaucratic advancement in China: not just performance in the functional sense of doing one's duties, but performance in the staging sense of doing one's duties for an audience, which consists of the bureaucrats' superiors. The success of any state-mandated campaign or program such as the RFFP is as much dependent on whether local officials charged with implementing it can demonstrate success according to certain evaluative criteria as it is on their meeting the practical goals of the program (Smith, 2013; Whiting, 2004). In the case of the RFFP, this means that officials will be judged successful not just on how rural livelihoods are improved or ecosystem services expanded, but also on how well they have met the criteria set out in the program's guidelines. This presents a paradox. On the one hand, real ecological or economic advancement can disappear behind the curtain of bureaucratic advancement, more often than not measured by initiation criteria such as numbers of trees planted or numbers of hectares retired, rather than according to outcome criteria such as number of trees surviving or income gained by local people. On the other hand, as long as superficial goals are met, officials and the communities they work with have great leeway to carry out the policy flexibly on (or in) the ground.

\subsection{The Significance of Ecological Forests}

Dual-function forests, officially classified as "ecological forests," also raise questions about how the term "ecological" in Chinese official discourse should be understood. The term shengtai, or "ecological" can be used almost interchangeably with other ambiguous terms such as "natural" (ziran), "sustainable" (kechixu), "environmental" (huanjing), or even "green" (lü se), and can refer to things as specific as soil chemistry and as vague as civilization (Ren 2013). Central authorities could justify maintaining the "ecological" classification of dual-function forests by pointing to how they still fulfill some environmental functions. What species of trees are planted to replace what crops and who gets how much subsidy or other income is open to local interpretation, as long as bureaucrats can show that they are fulfilling their mandates to advance "development" and "ecological civilization."

The ambiguity of the term "ecological forests" has created misconceptions both in the course of implementation and in broader perceptions of China's forest programs. On the ground, they provoke efforts to reconcile the term "ecological" with forests that do not appear to fit it. Residents and officials may see the term as merely an administrative distinction. Hence in one case study site, local officials explained that the designation as "ecological" forest was needed because the poverty of rural residents necessitated the longer compensation period associated with ecological forests, and that it had nothing to do with the character of the forests themselves.

Ecological forest or not, it might be expected that the opportunity to afforest with trees that would yield cash crops, while receiving compensation for a longer period, would lead to high rates of successful planting. This appears to have been the case in Hainan and Sanjiang, but not in Baiwu and Weixi. Implementation outcomes depended on how well prescribed trees and cultivation methods fit with biophysical conditions and residents' experiences. In Baiwu, potential dual-function forests failed because the species selected were either inappropriate 
altogether (Prinsepia and Robinia), or were planted in the wrong place (walnuts). In Weixi, residents were initially chary of walnut and Prinsepia trees, concerned about losing grain production and uncertain about the market prospects of walnuts and Prinsepia oil. As a result, in several communities residents did little to manage their dual-function forests. The same residents welcomed a second generation of walnut plantation that allowed interplanting and brought extension training in walnut cultivation. The full implications of these variations, which likely extend to RFFP sites across the country, cannot be evaluated without close observations of forest quality and management.

To what extent do dual-function forests promote the RFFP's environmental goals of soil retention, biodiversity conservation, and carbon sequestration? The answers depend on the benchmark for comparison. Relative to annual crops, depending on tillage and undergrowth management, orchards may have higher rates of evapotranspiration, reducing surface run-off (Radersma and de Ridder 1996); retain soil more effectively (Durán Zuazo and Rodríguez Pleguezuelo 2008); and sequester more carbon (Kroodsma and Field, 2006). If managed appropriately, they may host richer plant and animal communities than degraded or agricultural land (Parrotta et al., 1997). The picture is different if we compare RFFP orchards with native mixed forests. Monoculture tree plantations tend to have fewer native plant and animal species than regenerating natural forests (Barlow et al. 2007, Brockerhoff et al. 2008), though this relationship does not hold universally (Bremer and Farley, 2010). Soil retention and carbon sequestration in pulp plantations can be similar to those of naturally regenerating secondary forests (Sang et al., 2013). Contrasts are greater when the alternative is recovering tropical rainforest (Barlow et al., 2007; Chazdon, 2008; Kanowski et al., 2005), as in Hainan. If we compare dual-function forests with RFFP forests formally designated as commercial forests, there may not be an appreciable difference.

The extent to which a dual-function forest plantation brings specific benefits in any given case depends on species, environment, and management. Different plantation species fix carbon and retain soil at different rates and have different relationships with other organisms. Some walnut varieties emit allelopathic chemicals, inhibiting the growth of other vegetation (Rietveld 1983, Solar et al. 2006). Rubber plantations specifically have been found to provide poor habitat (Behm et al., 2013; Li et al., 2007) and to be inferior to intact rainforest in carbon sequestration and hydrological functions (Xu et al., 2014). Management further differentiates outcomes. Whether undergrowth is present is particularly consequential for habitat, soil retention, and carbon sequestration functions. Where undergrowth is cleared or grazed by livestock, these functions are likely to be impaired (Fuentealba and Martínez-Ramos, 2014). Both of these practices were present in some case study sites. We have also observed the application of chemical fertilizer and pesticide, which can weaken habitat function and cause soil and water pollution (Schwarzenbach et al., 2006). Interplanting of field crops, while accelerating tree growth with fertilization, can reduce habitat capacity, and plowing hampers soil retention. The various species selections and management practices identified in just these four cases suggest a much broader range of environmental and socioeconomic impacts than studies of RFFP to date have presented (see Table 3). 
Table 3. Addressing Tensions and Realizing Goals in Case Study Sites

\begin{tabular}{|c|c|c|c|c|}
\hline Case & Tension & Resolution & $\begin{array}{l}\text { Realizing Environmental } \\
\text { Goals }\end{array}$ & Realizing Productivist Goals \\
\hline Weixi & $\begin{array}{l}\text { Walnut trees as planted do } \\
\text { not produce. }\end{array}$ & $\begin{array}{l}\text { Allow crop } \\
\text { interplanting; allow } \\
\text { pine interplanting. }\end{array}$ & $\begin{array}{l}\text { Strongest when walnut } \\
\text { production abandoned, } \\
\text { second strongest when } \\
\text { people were allowed to } \\
\text { manage walnuts as } \\
\text { commercial groves. } \\
\end{array}$ & $\begin{array}{l}\text { Modest; strongest when } \\
\text { walnuts managed for } \\
\text { production, but in many } \\
\text { cases this did not happen. } \\
\text { People are primed for new } \\
\text { walnut cultivation. }\end{array}$ \\
\hline Caoxiu & $\begin{array}{l}\text { Initial kudingcha plantings } \\
\text { failed. }\end{array}$ & $\begin{array}{l}\text { Residents planted } \\
\text { houpu. }\end{array}$ & $\begin{array}{l}\text { Strong in short term, but } \\
\text { houpu harvest will bring } \\
\text { clear-cut. }\end{array}$ & $\begin{array}{l}\text { Residents anticipate long- } \\
\text { term gain from houpu. }\end{array}$ \\
\hline Baiwu & $\begin{array}{l}\text { Wasteland plantings failed, } \\
\text { as did walnut and } \\
\text { qingciguo. Poplar and } \\
\text { grazing conflicted. }\end{array}$ & $\begin{array}{l}\text { Residents planted } \\
\text { poplar and walnut; } \\
\text { poplar survived, } \\
\text { and grazing } \\
\text { lessened. } \\
\end{array}$ & $\begin{array}{l}\text { Variable. Poplar may help } \\
\text { restore stream channel. Many } \\
\text { mountain forest patches } \\
\text { regenerated naturally. }\end{array}$ & $\begin{array}{l}\text { Poor: commercial species all } \\
\text { died. Poplar could be used } \\
\text { commercially. Crops grown } \\
\text { on former fallow. }\end{array}$ \\
\hline Wuzhishan & $\begin{array}{l}\text { Natural forest regeneration } \\
\text { unprofitable; RFFP would } \\
\text { take land from growing } \\
\text { tree products industries }\end{array}$ & $\begin{array}{l}\text { Corporate pulp and } \\
\text { timber plantation; } \\
\text { household fruit and } \\
\text { rubber plantation. }\end{array}$ & $\begin{array}{l}\text { Strong on C sequestration. } \\
\text { Weak on biodiversity. } \\
\text { Middling on erosion, } \\
\text { depending on how } \\
\text { understory managed. } \\
\end{array}$ & $\begin{array}{l}\text { Strong, in bifurcated ways: } \\
\text { big corporate profits, also } \\
\text { substantial income for } \\
\text { residents. Both motivated to } \\
\text { keep this cover. }\end{array}$ \\
\hline
\end{tabular}

There is ample room for field-based research to evaluate these impacts. Published scholarship on the RFFP may give an exaggerated picture of its environmental benefits. Studies that rely on either government statistics or relatively coarse-grained remote sensing data give little insight into the composition and structure of forests. A reliable evaluation of the environmental impacts of the RFFP must be based on a more robust integration of field observations with remote sensing data to account for forest quality and management.

\section{Conclusion}

These cases of dual-function forests demonstrate the flexibility of state efforts to secure environmental values as well as how local actors' responses shape concrete policy outcomes. Responding to social and economic pressures that arose within the piloting process of RFFP, state actors adjusted the program to keep it viable. This flexibility can be salutary, enabling adjustment in the face of unexpected circumstances or unconsidered interests, but it brings risks that important priorities will be weakened. China confronts a number of serious environmental issues, and the forestry sector has shown that with concerted action it can achieve significant results. Nonetheless, in evaluating program outcomes, it is crucial to look closely at how official presentations relate to on-the-ground realities. In the case of dual-function forests, policy adjustment has arguably extended the possibilities for successful tree planting under the RFFP, but it has also blurred the actual environmental and social consequences of the program.

Local variation in RFFP outcomes has not received adequate attention. Studies tend either to downplay local variation, set it aside through statistical control, or to treat it as deviation to be rectified rather than as variation to be understood. Hence, evaluations of the RFFP tend to focus 
on the structure of incentives and other technical aspects of the program (e.g., Chen et al., 2009, 2010; Xu et al., 2010, Yin et al., 2010). Refining the technical components of RFFP policy is doubtless vital to making the RFFP and its successor policies work well for participants and landscapes. Indeed, dual-function forests manifest a technical component of the program that has been little recognized in the literature. But policy and its technicalities are not the whole story. The case studies in this article show that the actions of local actors in RFFP implementation raise questions that re-tuning compensation levels or monitoring protocols will not adequately address.

In late 2013, the State Forestry Administration announced that a "new round" (xin yi lun) of RFFP would be implemented starting in 2015 (State Forestry Administration, 2013). The new round dispenses altogether with the distinction between ecological and commercial forests, granting farmers autonomy to decide what trees to plant. Monitoring provisions are more specific, and compensation will take place on a multi-year schedule. Thus, it appears that the new round of RFFP carries on the developments that dual-function forests instantiated. We can expect that its impacts will depend on the actions and interactions of community residents and local officials tasked with turning a central vision into a panoply of tree-covered landscapes.

\section{Bibliography}

Barlow, J., Gardner, T.A., Araujo, I.S., Ávila-Pires, T.C., Bonaldo, A.B., Costa, J.E., Esposito, M.C., Ferreira, L.V., Hawes, J., Hernandez, M.I.M., Hoogmoed, M.S., Leite, R.N., Lo-Man-Hung, N.F., Malcolm, J.R., Martins, M.B., Mestre, L. a. M., Miranda-Santos, R., Nunes-Gutjahr, A.L., Overal, W.L., Parry, L., Peters, S.L., Ribeiro-Junior, M.A., Silva, M.N.F. da, Motta, C. da S., Peres, C.A., 2007. Quantifying the biodiversity value of tropical primary, secondary, and plantation forests. PNAS 104, 18555-18560. doi:10.1073/pnas.0703333104

Behm, J.E., Yang, X., Chen, J., 2013. Slipping through the Cracks: Rubber Plantation Is Unsuitable Breeding Habitat for Frogs in Xishuangbanna, China. PLoS ONE 8, e73688. doi:10.1371/journal.pone.0073688

Bennett, M.T., 2008. China's sloping land conversion program: Institutional innovation or business as usual? Ecological Economics 65, 699-711. doi:10.1016/j.ecolecon.2007.09.017

Blaikie, P.M., Muldavin, J.S.S., 2004. Upstream, Downstream, China, India: The Politics of Environment in the Himalayan Region. Annals of the Association of American Geographers 94, 520-548. doi:10.1111/j.1467-8306.2004.00412.x

Bremer, L.L., Farley, K.A., 2010. Does plantation forestry restore biodiversity or create green deserts? A synthesis of the effects of land-use transitions on plant species richness. Biodivers Conserv 19, 3893-3915. doi:10.1007/s10531-010-9936-4

Brockerhoff, E.G., Jactel, H., Parrotta, J.A., Quine, C.P., Sayer, J., 2008. Plantation forests and biodiversity: oxymoron or opportunity? Biodivers Conserv 17, 925-951. doi:10.1007/s10531008-9380-x

Bullock, A., King, B., 2011. Evaluating China's Slope Land Conversion Program as sustainable management in Tianquan and Wuqi Counties. Journal of Environmental Management 92, 1916-1922. doi:10.1016/j.jenvman.2011.03.002

Caldwell, I.M., Maclaren, V.W., Chen, J.M., Ju, W.M., Zhou, S., Yin, Y., Boland, A., 2007. An integrated assessment model of carbon sequestration benefits: A case study of Liping county, 
China. Journal of Environmental Management 85, 757-773.

doi:10.1016/j.jenvman.2006.08.020

Cao, S., Chen, L., Yu, X., 2009. Impact of China's Grain for Green Project on the landscape of vulnerable arid and semi-arid agricultural regions: a case study in northern Shaanxi Province. Journal of Applied Ecology 46, 536-543. doi:10.1111/j.1365-2664.2008.01605.x

Chazdon, R.L., 2008. Beyond Deforestation: Restoring Forests and Ecosystem Services on Degraded Lands. Science 320, 1458-1460. doi:10.1126/science.1155365

Chen, X., Lupi, F., He, G., Ouyang, Z., Liu, J., 2009. Factors affecting land reconversion plans following a payment for ecosystem service program. Biological Conservation 142, 1740-1747. doi:10.1016/j.biocon.2009.03.012

Chen, X., Lupi, F., Viña, A., He, G., Liu, J., 2010. Using Cost-Effective Targeting to Enhance the Efficiency of Conservation Investments in Payments for Ecosystem Services. Conservation Biology 24, 1469-1478. doi:10.1111/j.1523-1739.2010.01551.x

China Net, 2007. Press Briefing on the Returning Farmland to Forest Program Held by the State Forestry Administration, 2007. http:/ / www.china.com.cn/zhibo/200710/10/content_9021058.htm (in Chinese).

Durán Zuazo, V.H., Rodríguez Pleguezuelo, C.R., 2008. Soil-erosion and runoff prevention by plant covers. A review. Agron. Sustain. Dev. 28, 65-86. doi:10.1051/agro:2007062

Eaton, S., Kostka, G., 2014. Authoritarian Environmentalism Undermined? Local Leaders' Time Horizons and Environmental Policy Implementation in China. The China Quarterly FirstView, 1-22. doi:10.1017/S0305741014000356

Ediger, L., 2008. Frameworks for Farmland Afforestation in Rural China: An Assessment of Household-based and Collective Management, in: Jepson, W., Millington, A. (Eds.), Land Change Science in the Tropics. Springer US, New York, pp. 201-214.

Fuentealba, B.D., Martínez-Ramos, M., 2014. Transplanting native tree seedlings to enrich tropical live fences: an ecological and socio-economic analysis. Agroforest Syst 88, 221-236. doi:10.1007/s10457-013-9669-y

Greenpeace China, 2011. Disappearing Rainforests: Research Report on Change in The Tropical Natural Forests of Hainan, 2001-2010. Greenpeace China, Beijing (in Chinese).

Groom, B., Grosjean, P., Kontoleon, A., Swanson, T., Zhang, S., 2009. Relaxing rural constraints: a "win-win" policy for poverty and environment in China? Oxf. Econ. Pap. gpp021. doi:10.1093/oep/gpp021

Grosjean, P., Kontoleon, A., 2009. How Sustainable are Sustainable Development Programs? The Case of the Sloping Land Conversion Program in China. World Development 37, 268285. doi:10.1016/j.worlddev.2008.05.003

Harrell, S. and Aga R. 2013. Education or Migrant Labor: A New Dilemma in China's Borderlands. The Asia Pacific Journal 20 (1): http:/ /japanfocus.org/-Stevan-Harrell/3939 He, J., Lang, R., 2015. Limits of State-Led Programs of Payment for Ecosystem Services: Field Evidence from the Sloping Land Conversion Program in Southwest China. Human Ecology 43, 749-758. doi:10.1007/s10745-015-9782-9

Hecht, S.B., 2014. Forests lost and found in tropical Latin America: the woodland "green revolution." Journal of Peasant Studies 41,877-909. doi:10.1080/03066150.2014.917371

Kanowski, J., Catterall, C.P., Wardell-Johnson, G.W., 2005. Consequences of broadscale timber plantations for biodiversity in cleared rainforest landscapes of tropical and subtropical Australia. Forest Ecology and Management 208, 359-372. doi:10.1016/j.foreco.2005.01.018 
Kelly, P., Huo, X., 2013a. Do farmers or governments make better land conservation choices? Evidence from China's Sloping Land Conversion Program. Journal of Forest Economics 19, 32-60. doi:10.1016/j.jfe.2012.08.002

Kelly, P., Huo, X., 2013b. Land Retirement and Nonfarm Labor Market Participation: An Analysis of China's Sloping Land Conversion Program. World Development 48, 156-169. doi:10.1016/j.worlddev.2013.04.002

Kroodsma, D.A., Field, C.B., 2006. Carbon sequestration in california agriculture, 1980-2000. Ecological Applications 16, 1975-1985. doi:10.1890/10510761(2006)016[1975:CSICA]2.0.CO;2

Lambin, E.F., Meyfroidt, P., 2010. Land use transitions: Socio-ecological feedback versus socioeconomic change. Land Use Policy, Forest transitions Wind power planning, landscapes and publics 27, 108-118. doi:10.1016/j.landusepol.2009.09.003

Lee, C.K., Zhang, Y., 2013. The Power of Instability: Unraveling the Microfoundations of Bargained Authoritarianism in China. American Journal of Sociology 118, 1475-1508. doi:10.1086/670802

Li, H., Aide, T.M., Ma, Y., Liu, W., Cap, M., 2007. Demand for rubber is causing the loss of high diversity rain forest in SW China. Biodiversity and Conservation 16, 1731-1745.

Li, J., 2004. Report on the Implementation of the Returning Farmland to Forest Program in Yunnan Province. Kunming, China. http:/ / www.srd.yn.gov.cn/ynrdcwh/1013038336786300928/20091023/203464.html (in Chinese).

Lindblom, C.E., 1959. The Science of "Muddling Through." Public Administration Review 19, 79-88.

Litzinger, R., 2004. The Mobilization of Nature: Perspectives from North-West Yunnan. The China Quarterly 178, 488-504.

Liu, J., Li, S., Ouyang, Z., Tam, C., Chen, X., 2008. Ecological and socioeconomic effects of China's policies for ecosystem services. Proceedings of the National Academy of Sciences 105, 9477-9482. doi:10.1073/pnas.0706436105

Long, T., 2008. Analysis of Afforestation Species and Their Effectiveness in the Returning Farmland to Forest Program in Yunnan Province. Forest Construction 18-22 (in Chinese).

Lora-Wainwright, A., 2013. Introduction. Dying for Development: Pollution, Illness and the Limits of Citizens' Agency in China. The China Quarterly 214, 243-254. doi:10.1017/S0305741013000313

Lugo, A.E., 2009. The Emerging Era of Novel Tropical Forests. Biotropica 41, 589-591. doi:10.1111/j.1744-7429.2009.00550.x

Lü, Y., Fu, B., Feng, X., Zeng, Y., Liu, Y., Chang, R., Sun, G., Wu, B., 2012. A Policy-Driven Large Scale Ecological Restoration: Quantifying Ecosystem Services Changes in the Loess Plateau of China. PLoS ONE 7, e31782. doi:10.1371/journal.pone.0031782

Mertha, A.C., 2009. ?Fragmented Authoritarianism 2.0?: Political Pluralization in the Chinese Policy Process. The China Quarterly 200, 995-1012. doi:10.1017/S0305741009990592

Meyfroidt, P., Lambin, E.F., 2011. Global Forest Transition: Prospects for an End to Deforestation. Annual Review of Environment and Resources 36, 343-371. doi:10.1146/annurev-environ-090710-143732

Michelson, E., 2008. Justice from Above or Below? Popular Strategies for Resolving Grievances in Rural China. The China Quarterly 193, 43-64. doi:10.1017/S0305741008000039

$\mathrm{Mu}, \mathrm{C} ., \mathrm{Liu}, \mathrm{W} ., 2014$. Yunnan brews plans for expansion of coffee crop. China Daily. 
O’Brien, K., Li, L., 1999. Selective Policy Implementation in Rural China. Comparative Politics 31, 167-186.

Parrotta, J.A., Turnbull, J.W., Jones, N., 1997. Catalyzing native forest regeneration on degraded tropical lands. Forest Ecology and Management 99, 1-7. doi:10.1016/S0378-1127(97)00190-4

Radersma, S., de Ridder, N., 1996. Computed evapotranspiration of annual and perennial crops at different temporal and spatial scales using published parameter values. Agricultural Water Management 31, 17-34. doi:10.1016/0378-3774(95)01235-4

Ren Zhongping, 2013. Shengtai wenming de zhongguo juexing (The awakening of ecological civilization in China). Renmin Ribao (People's Daily), July 22, page 1.

Rietveld, W.J., 1983. Allelopathic effects of juglone on germination and growth of several herbaceous and woody species. J Chem Ecol 9, 295-308. doi:10.1007/BF00988047

Robbins, A.S.T., Harrell, S., 2014. Paradoxes and Challenges for China's Forests in the Reform Era. The China Quarterly FirstView, 1-23. doi:10.1017/S0305741014000344

Rudel, T.K., 2013. Defensive Environmentalists and the Dynamics of Global Reform. Cambridge University Press, New York.

Rudel, T.K., Coomes, O.T., Moran, E., Achard, F., Angelsen, A., Xu, J., Lambin, E., 2005. Forest transitions: towards a global understanding of land use change. Global Environmental Change 15, 23-31. doi:10.1016/j.gloenvcha.2004.11.001

Sang, P.M., Lamb, D., Bonner, M., Schmidt, S., 2013. Carbon sequestration and soil fertility of tropical tree plantations and secondary forest established on degraded land. Plant Soil 362, 187-200. doi:10.1007/s11104-012-1281-9

Schmitt, E.A., 2014. The History and Development of De-swiddening among the Ersu in Sichuan, China. Himalaya 34, 97-110.

Schwarzenbach, R.P., Escher, B.I., Fenner, K., Hofstetter, T.B., Johnson, C.A., Gunten, U. von, Wehrli, B., 2006. The Challenge of Micropollutants in Aquatic Systems. Science 313, 1072 1077. doi:10.1126/science.1127291

Scott, J.C., 1998. Seeing Like a State: How Certain Schemes to Improve the Human Condition Have Failed. Yale University Press, New Haven.

Smith, G., 2013. Measurement, promotions and patterns of behavior in Chinese local government. Journal of Peasant Studies 40, 1027-1050. doi:10.1080/03066150.2013.866095

Solar, A., Colarič, M., Usenik, V., Stampar, F., 2006. Seasonal variations of selected flavonoids, phenolic acids and quinones in annual shoots of common walnut (Juglans regia L.). Plant Science 170, 453-461. doi:10.1016/j.plantsci.2005.09.012

Song, C., Zhang, Y., Mei, Y., Liu, H., Zhang, Z., Zhang, Q., Zha, T., Zhang, K., Huang, C., Xu, X., Jagger, P., Chen, X., Bilsborrow, R., 2014. Sustainability of Forests Created by China's Sloping Land Conversion Program: A comparison among three sites in Anhui, Hubei and Shanxi. Forest Policy and Economics 38, 161-167. doi:10.1016/j.forpol.2013.08.012

State Council, 2002.Articles for the Returning Farmland to Forest Program (in Chinese).

State Council, 2007. Notice of the State Council on Completing the Returning Farmland to Forest Policy (in Chinese).

State Forestry Administration, 2002. Classification Standards for Ecological Forests and Commercial Forests under the Returning Farmland to Forest Program (in Chinese).

State Forestry Administration, 2004. Notice of the State Forestry Administration concerning Further Improving Work toward Consolidating the Accomplishments of the Returning Farmland to Forest Program (in Chinese). 
State Forestry Administration, 2006. A Report for Monitoring and Assessment of the Socioeconomic Impacts of China's Key Forestry Programs 2005. China Forestry Publishing Company, Beijing (in Chinese).

State Forestry Administration, 2013. Returning Farmland to Forest: Looking Forward to Beginning Anew. http://tghl.forestry.gov.cn/portal/tghl/s/3815/content-617743.html (in Chinese).

State Forestry Administration, 2014. 2013 National Monitoring Report on the Ecological Effectiveness of the Returning Farmland to Forest Program. China Forestry Publishing Company, Beijing (in Chinese).

Sturgeon, J.C., 2010. Governing minorities and development in Xishuangbanna, China: Akha and Dai rubber farmers as entrepreneurs. Geoforum 41, 318-328.

Tilt, B., 2014. Dams and Development in China: The Moral Economy of Water and Power. Columbia University Press, New York.

Trac, C., Harrell, S., Hinckley, T., Henck, A., 2007. Reforestation programs in Southwest China: Reported success, observed failure, and the reasons why. Journal of Mountain Science 4, 275-292. doi:10.1007/s11629-007-0275-1

Trac, C., Schmidt, A., Harrell, S., Hinckley, T., 2013. Is the Returning Farmland to Forest Program a Success? Three Case Studies from Sichuan. Environmental Practice 15, 350-366. doi:10.1017/S1466046613000355

Urgenson, L., Hagmann, R., Henck, A., Harrell, S., Hinckley, T., Shepler, S., Grub, B., Chi, P., 2010. Social-ecological Resilience of a Nuosu Community-linked Watershed, Southwest Sichuan, China. Ecology and Society 15.

van Rooij, B., Wainwright, A.L., Wu, Y., Zhang, Y., 2011. Compensation Trap: The Limits of Community-Based Pollution Regulation in China, The. Pace Envtl. L. Rev. 29, Article 2.

Wandesforde-Smith, G., Denninger Snyder, K., Hart, L.A., 2014. Biodiversity Conservation and Protected Areas in China: Science, Law, and the Obdurate Party-State. Journal of International Wildlife Law \& Policy 17, 85-101. doi:10.1080/13880292.2014.953371

Wang, C., Maclaren, V., 2012. Evaluation of economic and social impacts of the sloping land conversion program: A case study in Dunhua County, China. Forest Policy and Economics 14, 50-57. doi:10.1016/j.forpol.2011.06.002

Wang, P., Wolf, S.A., Lassoie, J.P., Dong, S., 2013. Compensation policy for displacement caused by dam construction in China: An institutional analysis. Geoforum 48, 1-9. doi:10.1016/j.geoforum.2013.04.009

Weidner, M., 2013. Conversion of Cropland to Forest and Grassland: Livlelihood Impact of a PES program (M.S. Thesis). Madison, WI, University of Wisconsin-Madison.

Whiting, S.H., 2004. The Cadre Evaluation System at the Grassroots: The Paradox of Party Rule, in: Naughton, B., Yang, D. (Eds.), Holding China Together: Diversity and National Integration in the Post-Deng Era. Cambridge University Press, Cambridge, UK, pp. 101-119.

Wu S., Li X., 2007. An Initial Exploration of Management Models within the Returning Farmland to Forest Program in Wuzhishan City, Hainan. Tropical Forestry 35, 7-9 (in Chinese).

Xu, J., Cao, Y., 2002. The Socioeconomic Impacts and Sustainability of the SLCP, in: Xu, J., Katsigris, E., White, T.A. (Eds.), Implementing the Natural Forest Protection Program and the Sloping Land Conversion Program: Lessons and Policy Recommendations. China Council for International Cooperation on Environment and Development, Beijing, pp. 52-61. 
Xu, J., Grumbine, R.E., Beckschäfer, P., 2014. Landscape transformation through the use of ecological and socioeconomic indicators in Xishuangbanna, Southwest China, Mekong Region. Ecological Indicators 36, 749-756. doi:10.1016/j.ecolind.2012.08.023

Xu, J., Tao, R., Xu, Z., Bennett, M.T., 2010. China's Sloping Land Conversion Program: Does Expansion Equal Success? Land Economics 86, 219-244.

Xu, J., Yin, R., Li, Z., Liu, C., 2006. China's ecological rehabilitation: Unprecedented efforts dramatic impacts, and requisite policies. Ecological Economics 57, 595- 607.

Yan Lizhen, Min Qingwen, 2004. Discussion on Concept and Proportion of Economic Forest and Ecologic Forest in Returning Cultivated Land to Forest. Research of Soil and Water Conservation 11, 50-53 (in Chinese).

Yeh, E.T., 2005. Green Governmentality and Pastoralism in Western China: "Converting Pastures to Grasslands." Nomadic Peoples 9, 9-30.

Yeh, E.T., 2009. Greening western China: A critical view. Geoforum 40, 884-894. doi:10.1016/j.geoforum.2009.06.004

Yin, R., Liu, C., Zhao, M., Yao, S., Liu, H., 2014. The implementation and impacts of China's largest payment for ecosystem services program as revealed by longitudinal household data. Land Use Policy, Land Use Policy in China 40, 45-55. doi:10.1016/j.landusepol.2014.03.002

Yin, R.S., Yao, S.B., Huo, X.X., 2013. Deliberating How to Resolve the Major Challenges Facing China's Forest Tenure Reform and Institutional Change. International Forestry Review 15, 534-543. doi:10.1505/146554813809025739

Yin, R., Yin, G., 2010. China's Primary Programs of Terrestrial Ecosystem Restoration: Initiation, Implementation, and Challenges. Environmental Management 45, 429-441. doi:10.1007/s00267-009-9373-x

Yin, R., Yin, G., Li, L., 2010. Assessing China's Ecological Restoration Programs: What's Been Done and What Remains to Be Done? Environmental Management 45, 442-453. doi:10.1007/s00267-009-9387-4

Yunnan Province Office of the Great Western Development Program, Yunnan Province Development and Reform Committee, Yunnan Province Forestry Department, 2004. Notice of the Provincial Western Development Office and Other Agencies of Opinions on Further Strengthening Work on Returning Farmland to Forest (in Chinese).

Zhai, D.-L., Cannon, C.H., Slik, J.W.F., Zhang, C.-P., Dai, Z.-C., 2012. Rubber and pulp plantations represent a double threat to Hainan's natural tropical forests. Journal of Environmental Management 96, 64-73. doi:10.1016/j.jenvman.2011.10.011

Zhai, D.-L., Xu, J.-C., Dai, Z.-C., Cannon, C.H., Grumbine, R.E., 2013. Increasing tree cover while losing diverse natural forests in tropical Hainan, China. Reg Environ Change 1-11. doi:10.1007/s10113-013-0512-9

Zhang J., Xue S., 2007. Survey Research on the Progress of Returning Farmland to Forest and Follow-up Policies in Our Province. Shaanxi Synthetic Economy 23-26 (in Chinese).

Zhang Maoqin, Zuo Xiandong, 2004. Exploration on Tree Species Selection for the Forest Rehabil itation Project. Journal of West China Forestry Science 33, 38-43 (in Chinese).

Zhao Xiaoqing, Lü Xing, Yuan Qing, Li Xianghua, 2004. An Exploration of the Situation of Retired Farmland and Models for Its Development in the Zhongyuan Watershed in Nujiang. Tropical Geography 24, 163-167 (in Chinese).

Zhen, N., Fu, B., Lü, Y., Zheng, Z., 2014. Changes of livelihood due to land use shifts: A case study of Yanchang County in the Loess Plateau of China. Land Use Policy, Land Use Policy in China 40, 28-35. doi:10.1016/j.landusepol.2013.05.004 
Zhou, D., Zhao, S., Zhu, C., 2012. The Grain for Green Project induced land cover change in the Loess Plateau: A case study with Ansai County, Shanxi Province, China. Ecological Indicators 23, 88-94. doi:10.1016/j.ecolind.2012.03.021

Zinda, J.A., 2014. Making National Parks in Yunnan: Shifts and Struggles within the Ecological State, in: Yeh, E.T., Coggins, C.R. (Eds.), Mapping Shangrila: Nature, Personhood and Polity in the Sino-Tibetan Borderlands. University of Washington Press, Seattle, pp. 105-128. 
Figure 1, color version
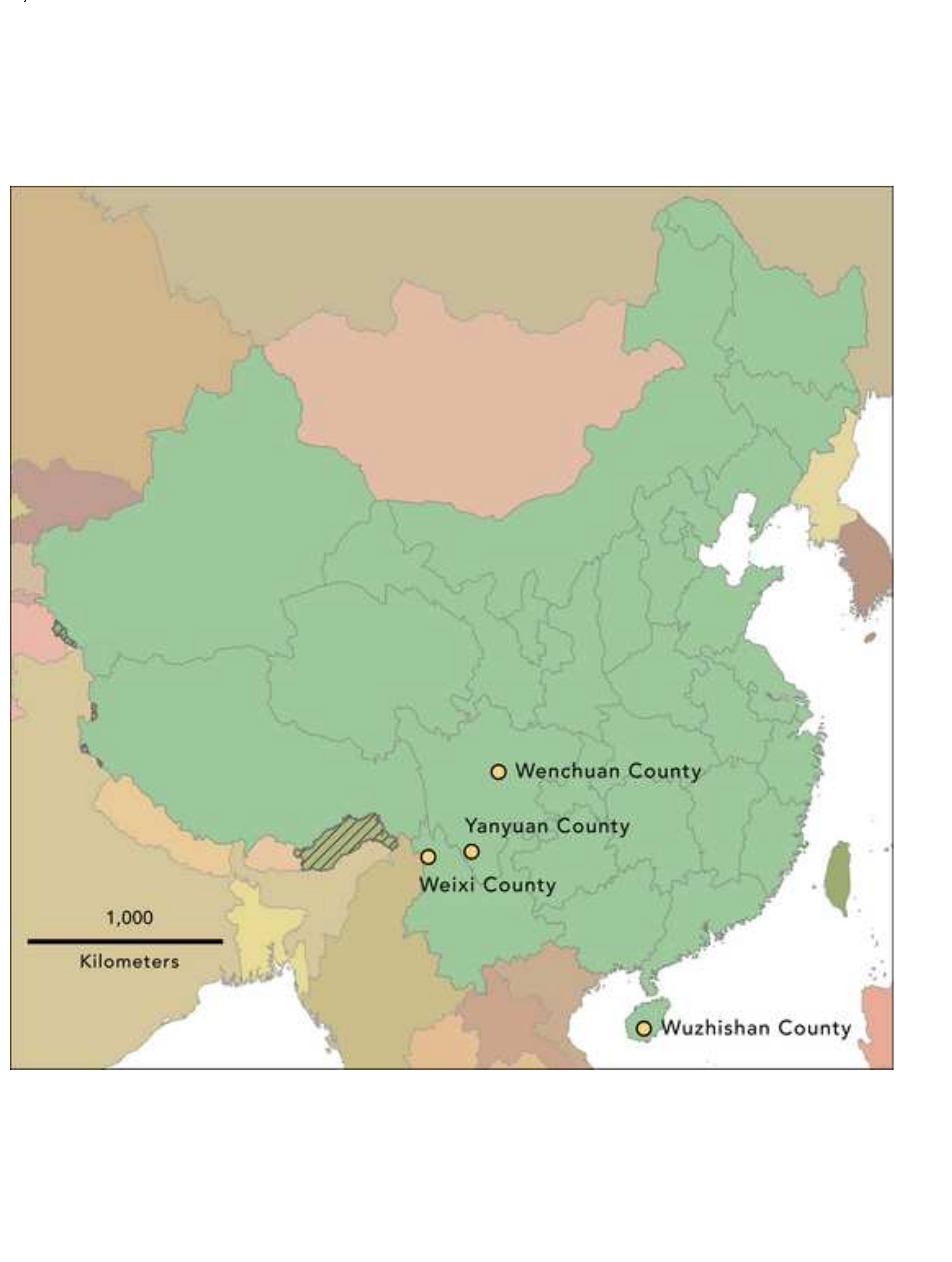


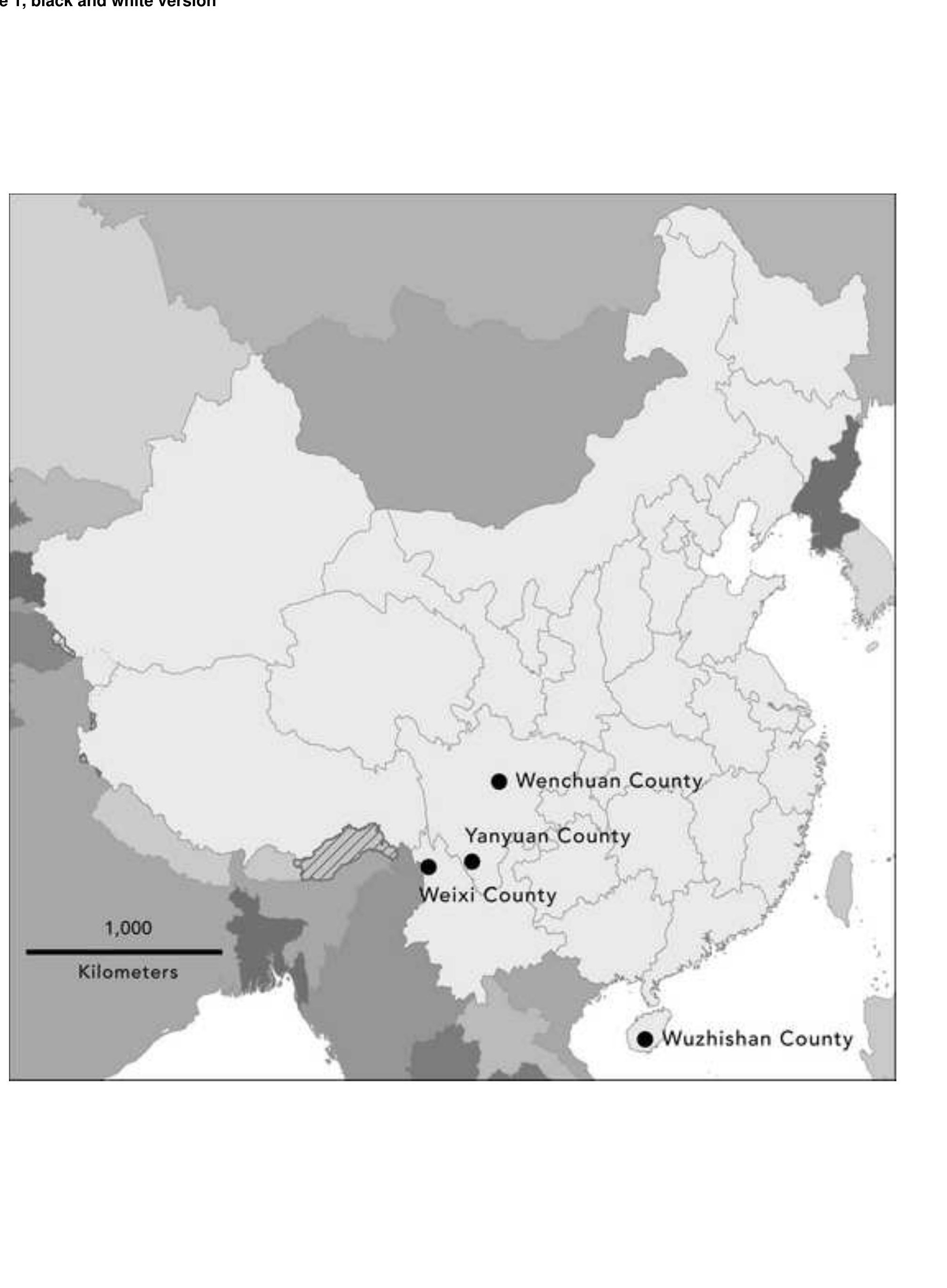

Figure 1, black and white version

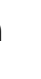

Kilometers 

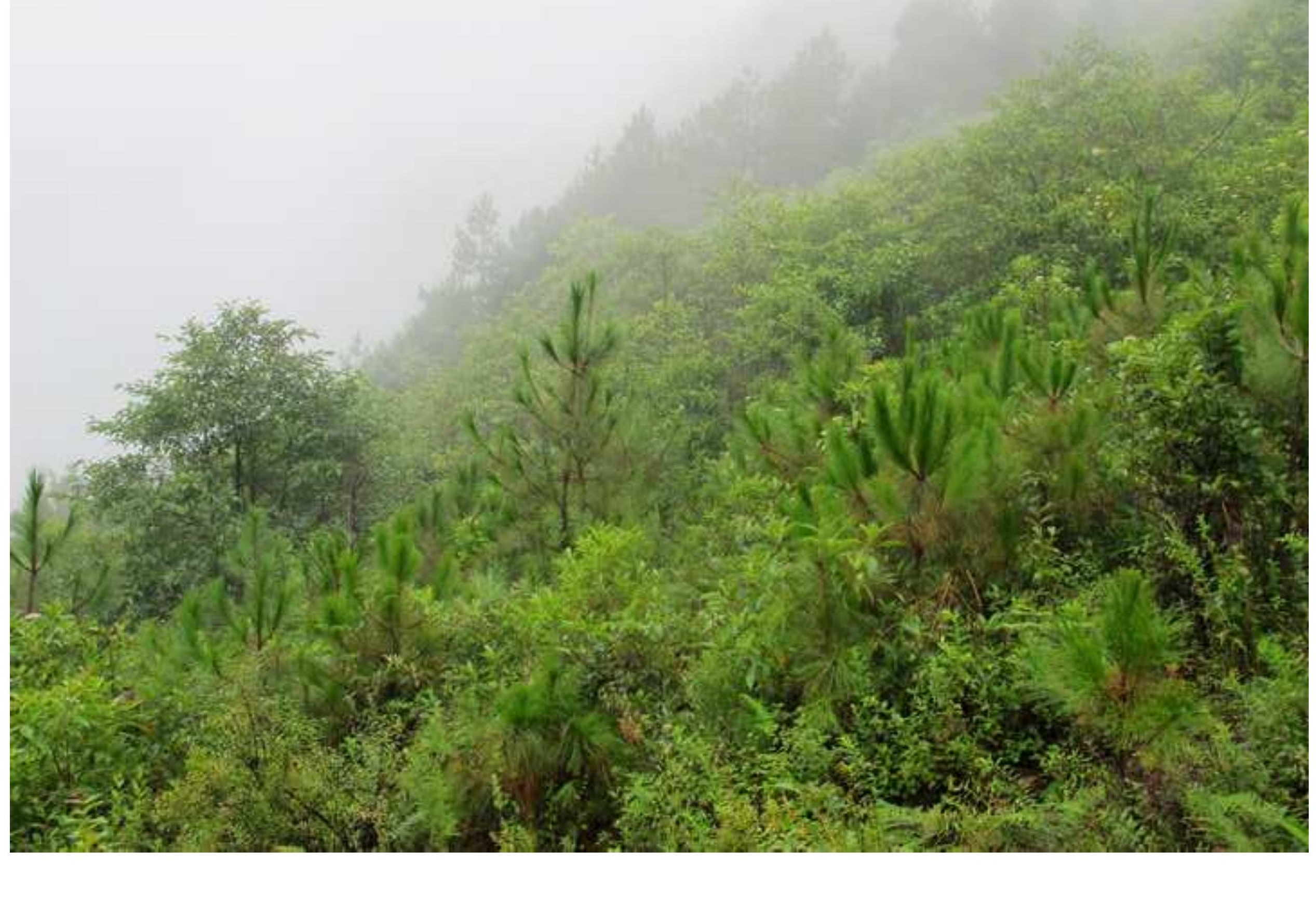


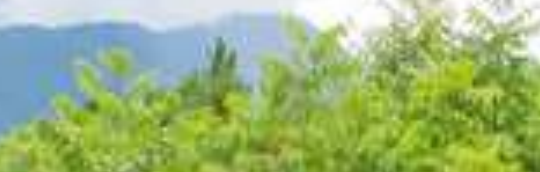

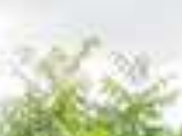

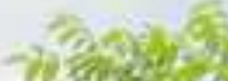

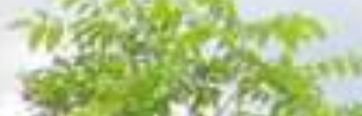

$x^{2}+x^{2}+3$

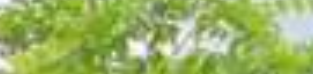

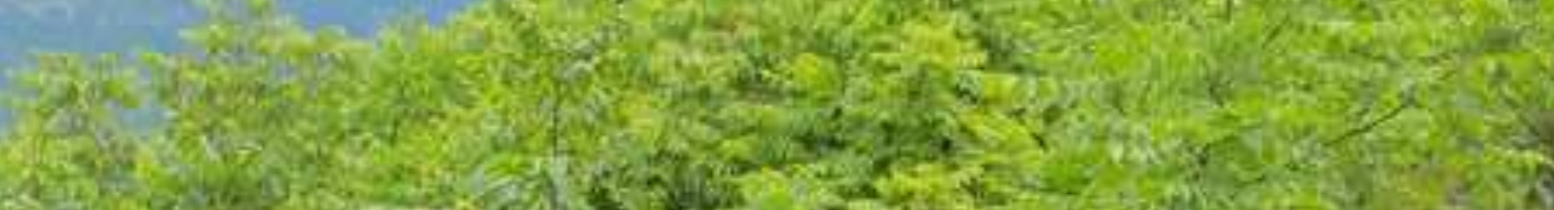

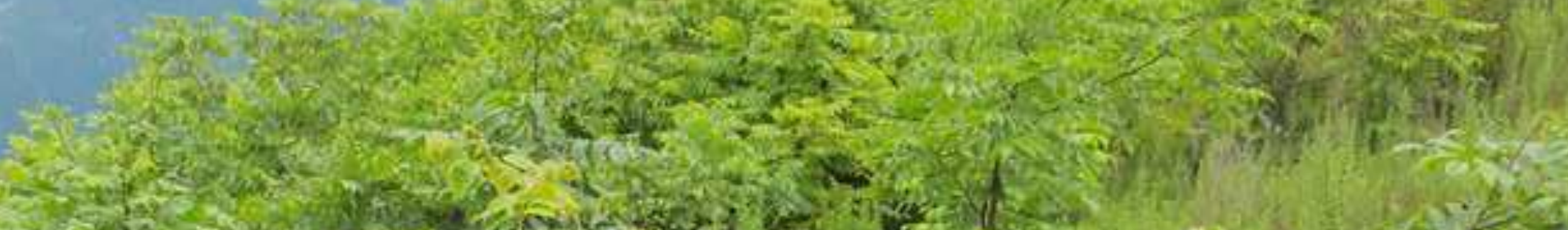

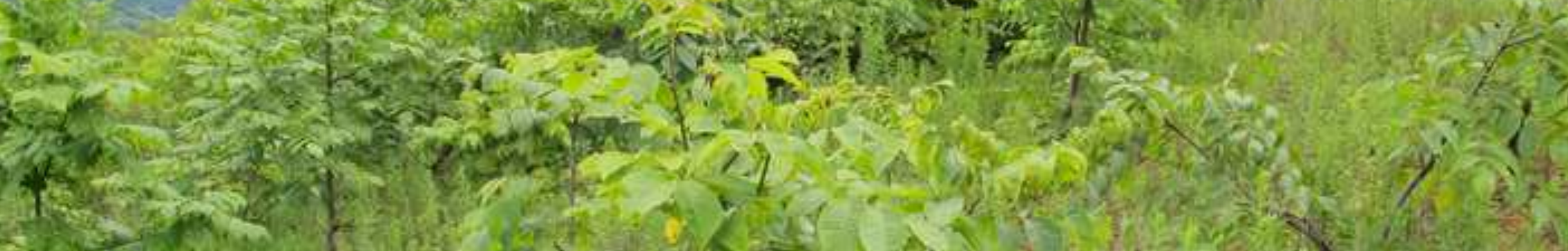
(3)

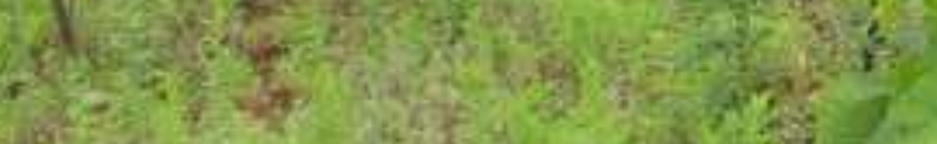

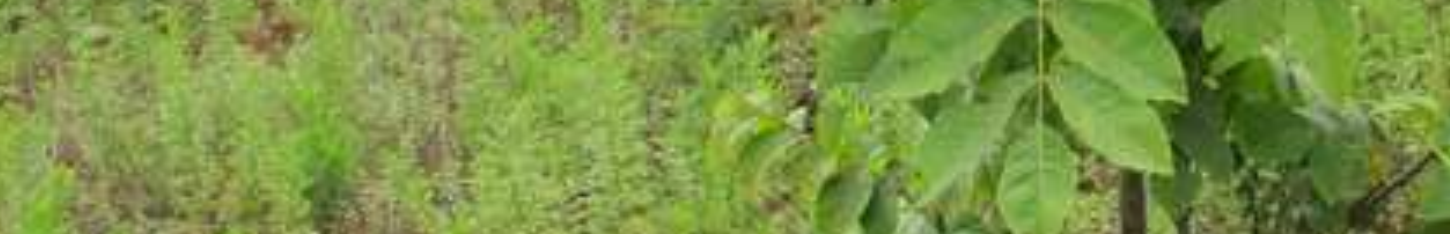

mo

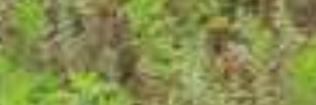

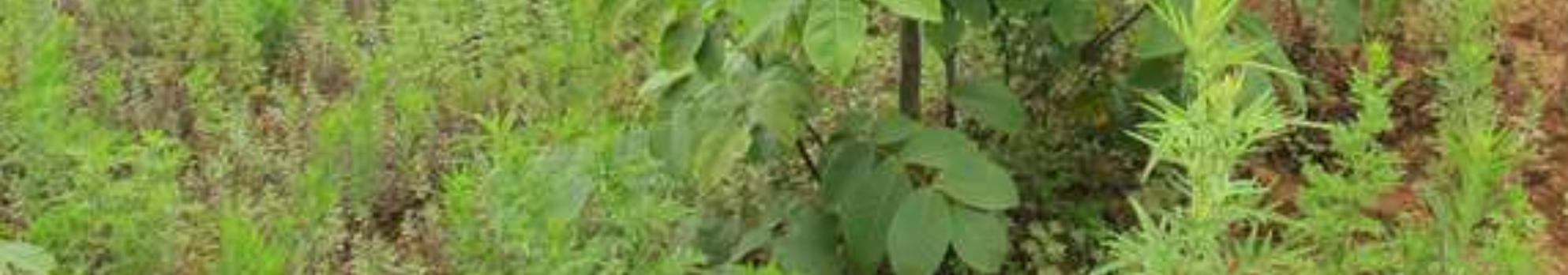

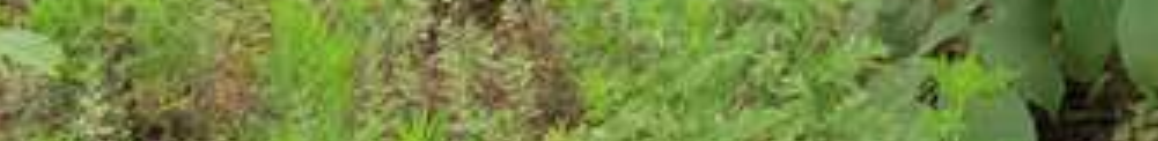
(5)

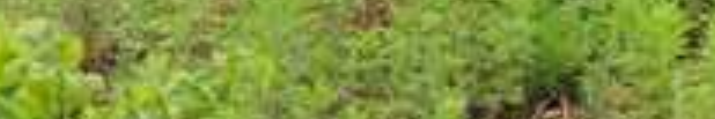
$\cos ^{2}$ SW (19)

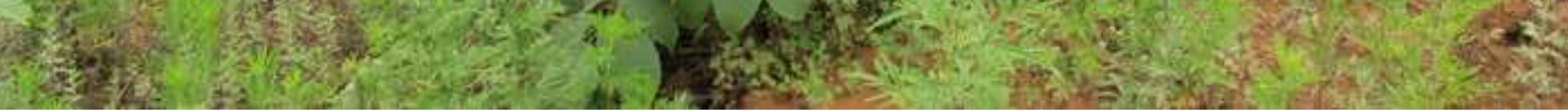




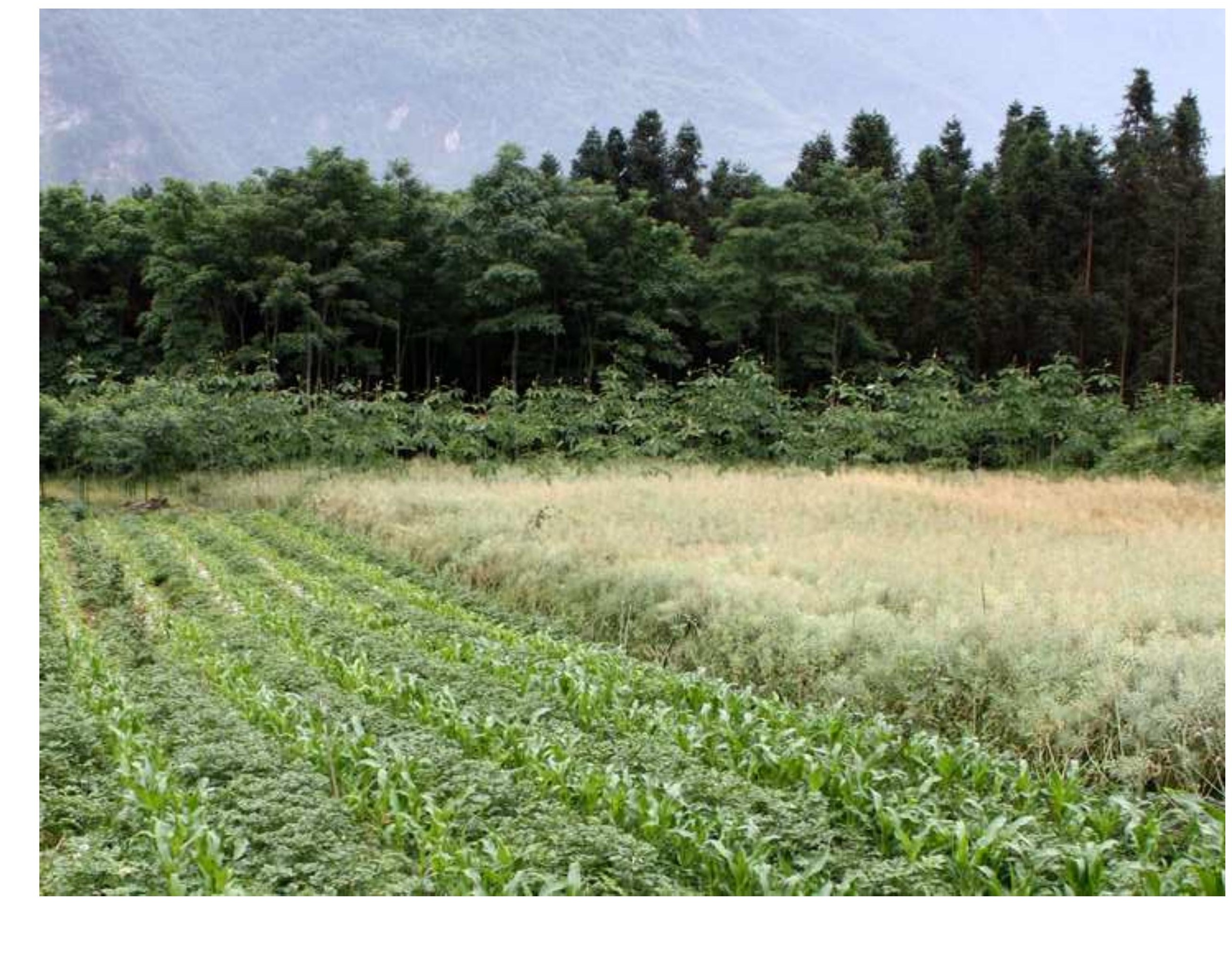

(b

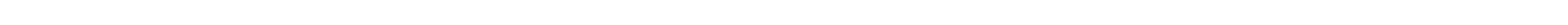



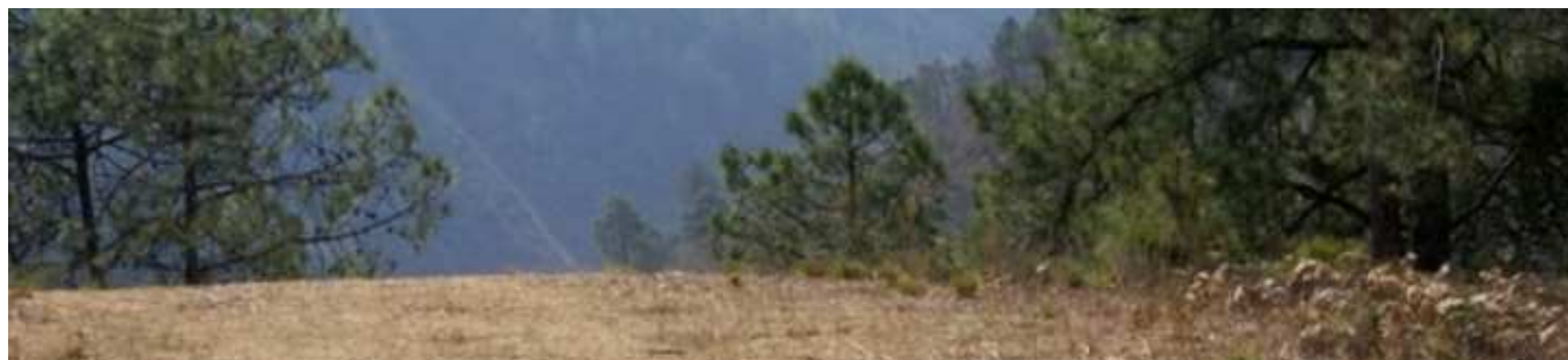

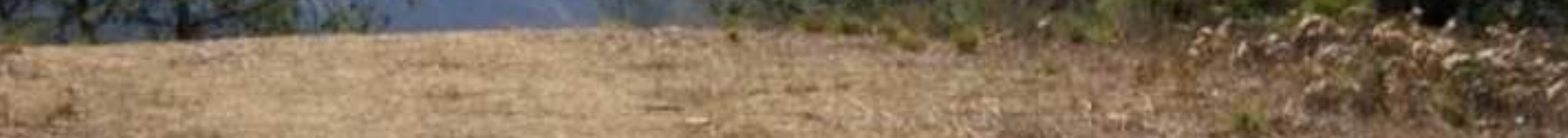

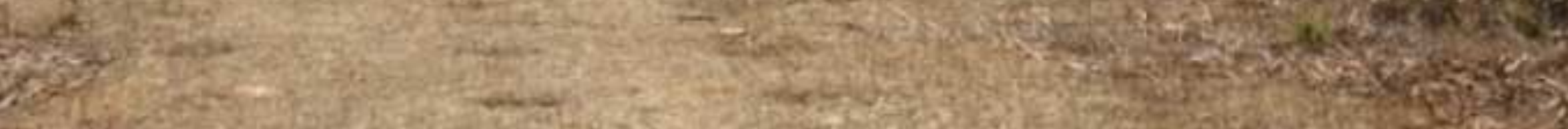

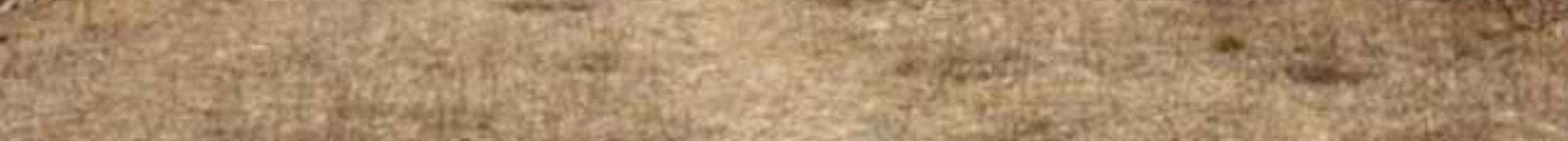
3
-1 Q

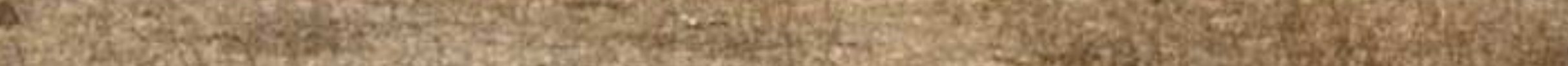

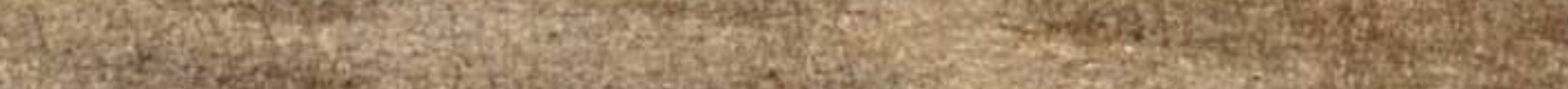

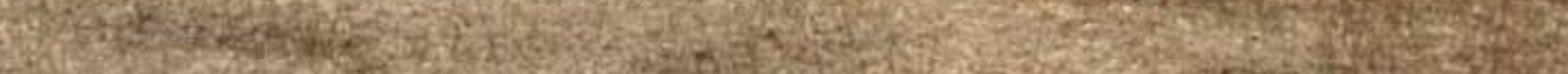

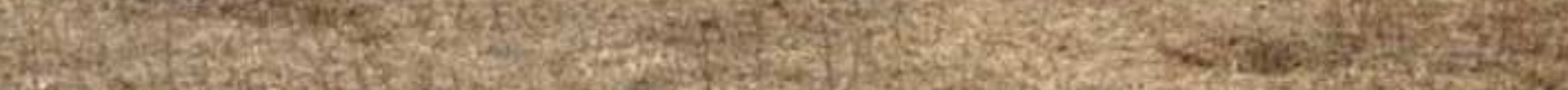
We

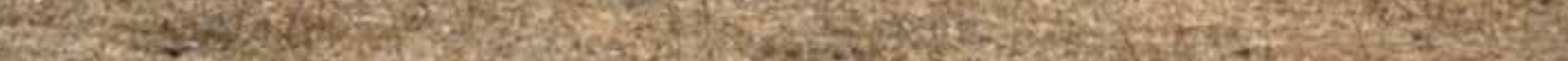
W.

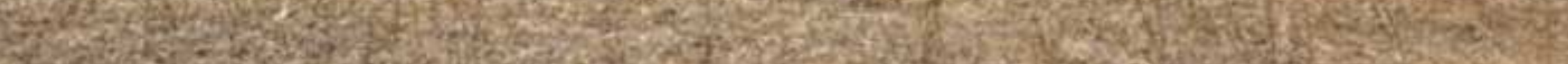

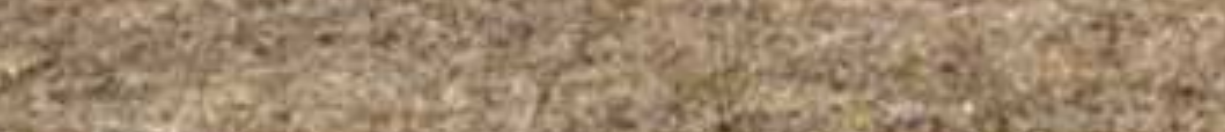

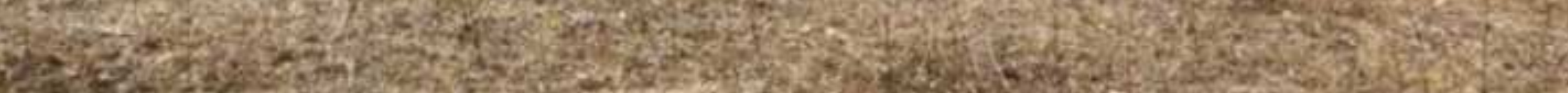
Non

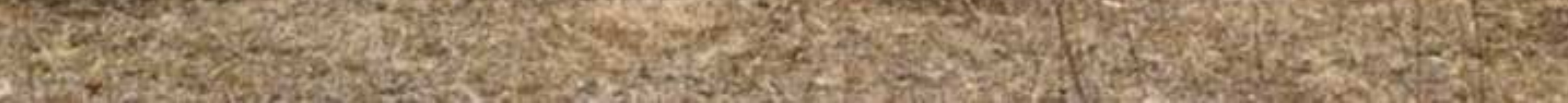




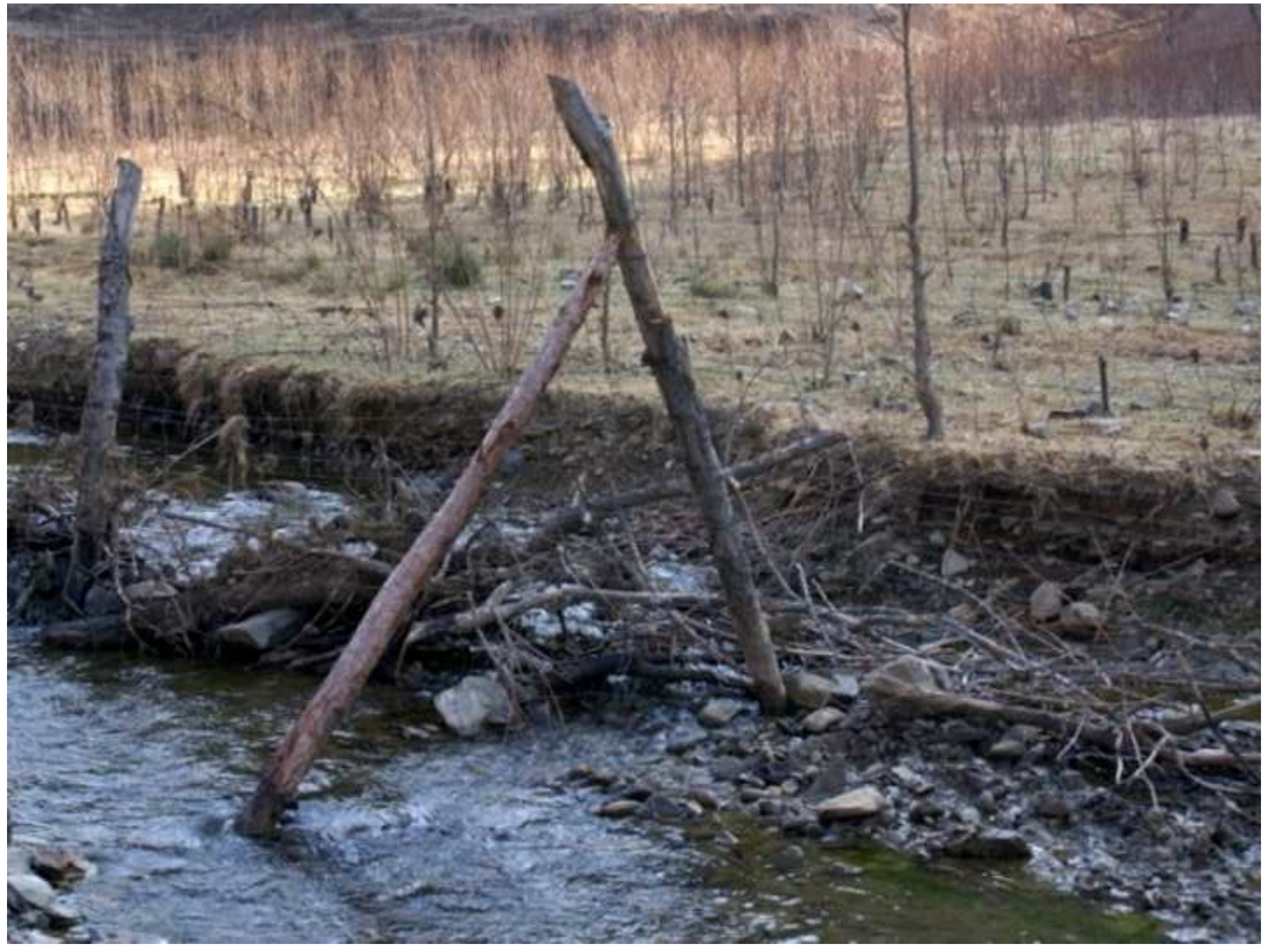

\section{सर्या}

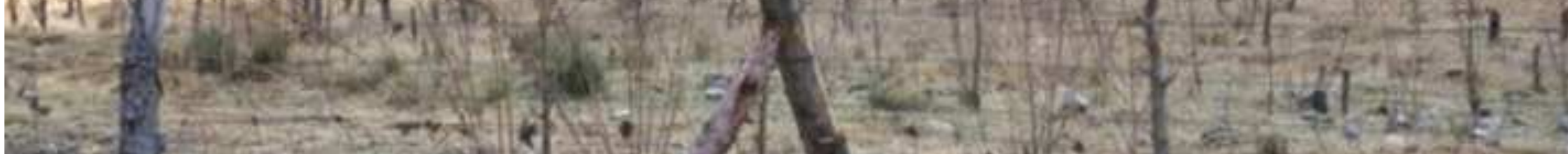

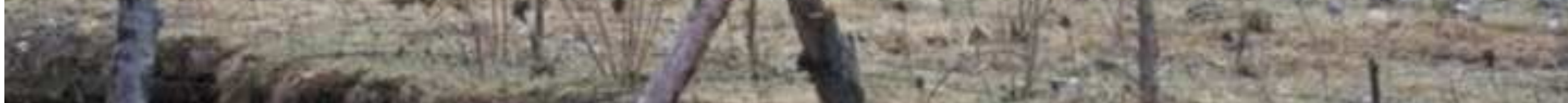

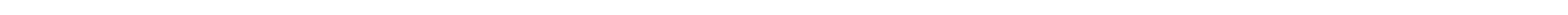

.

(1)

What

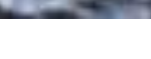




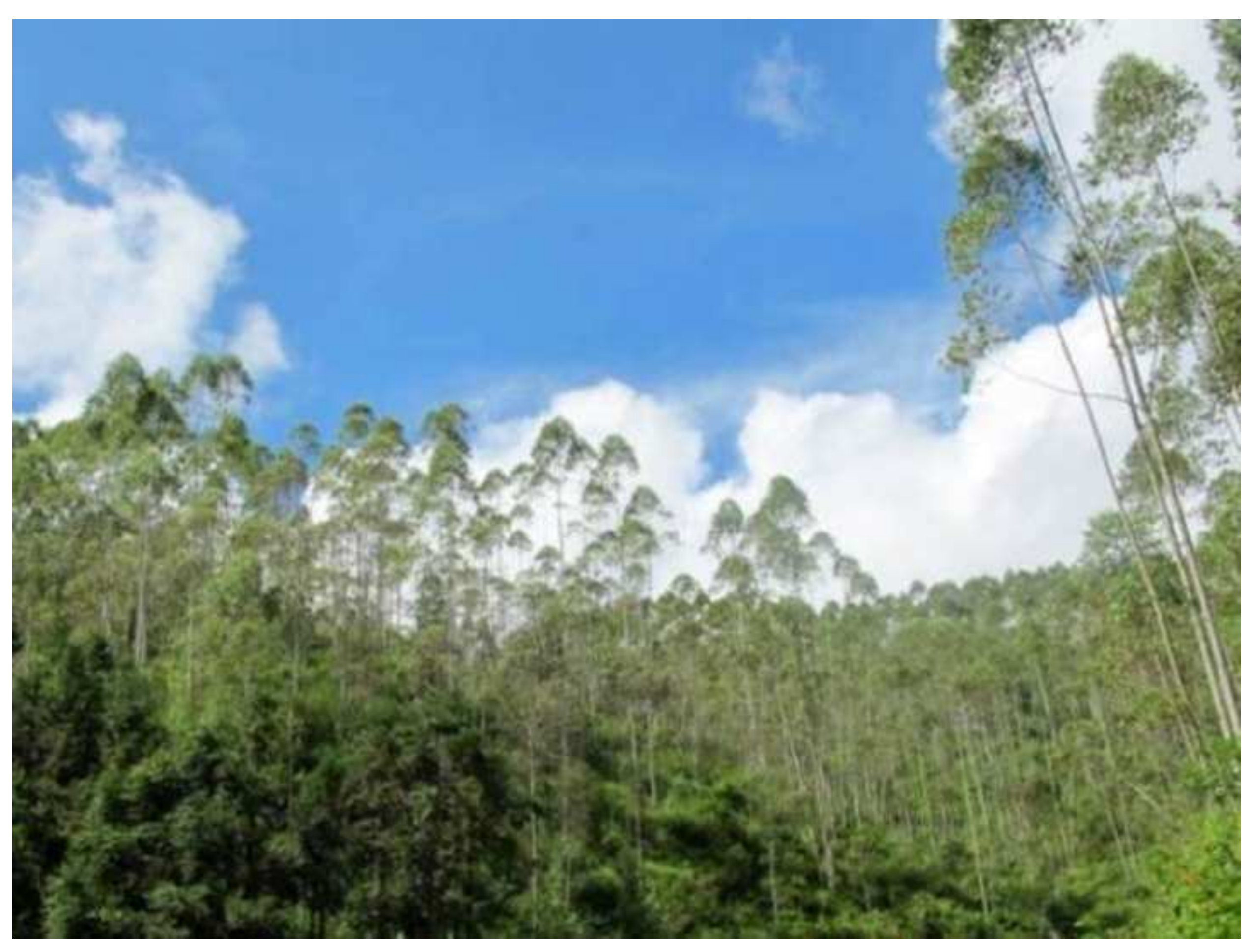

Figure 5
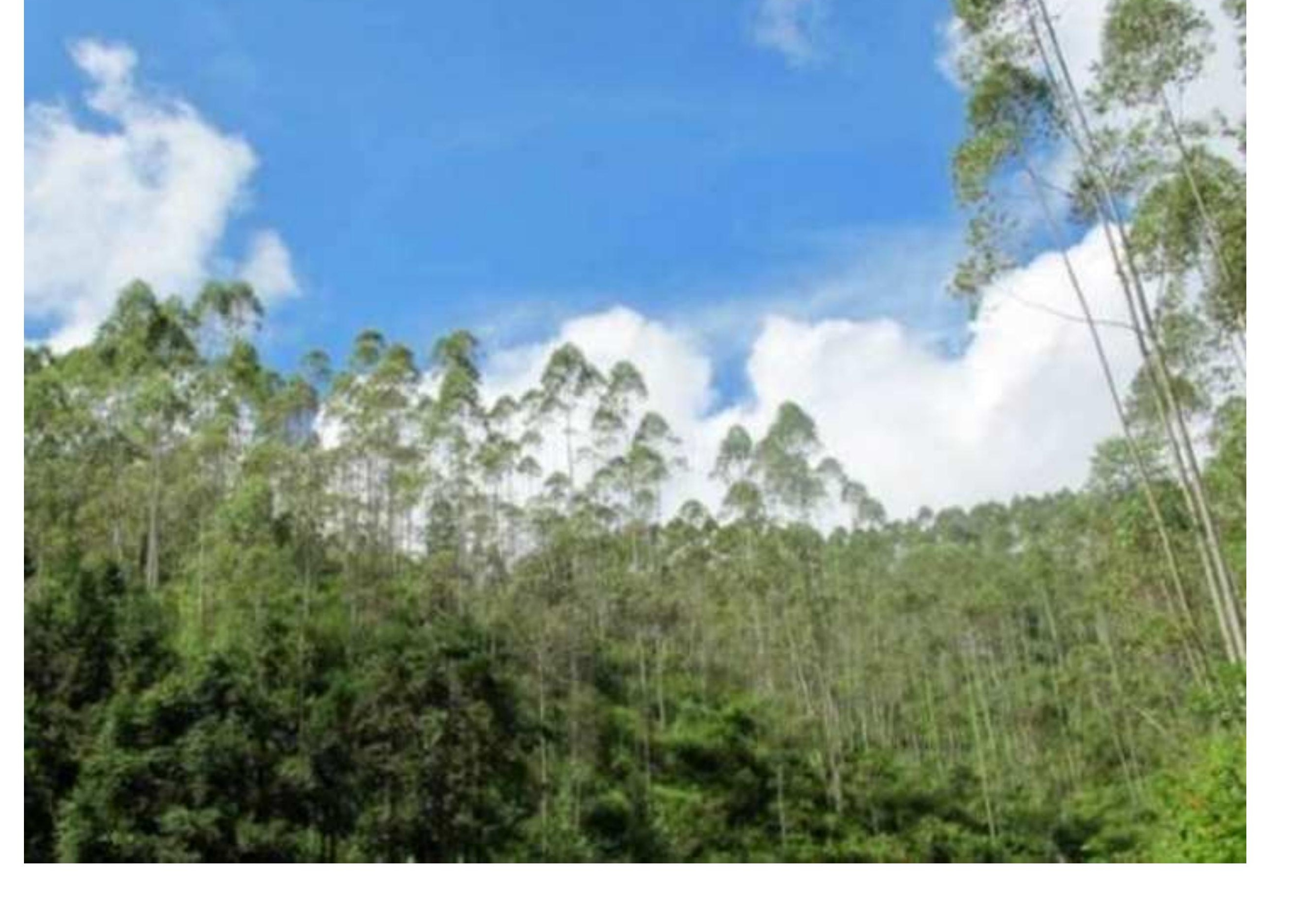


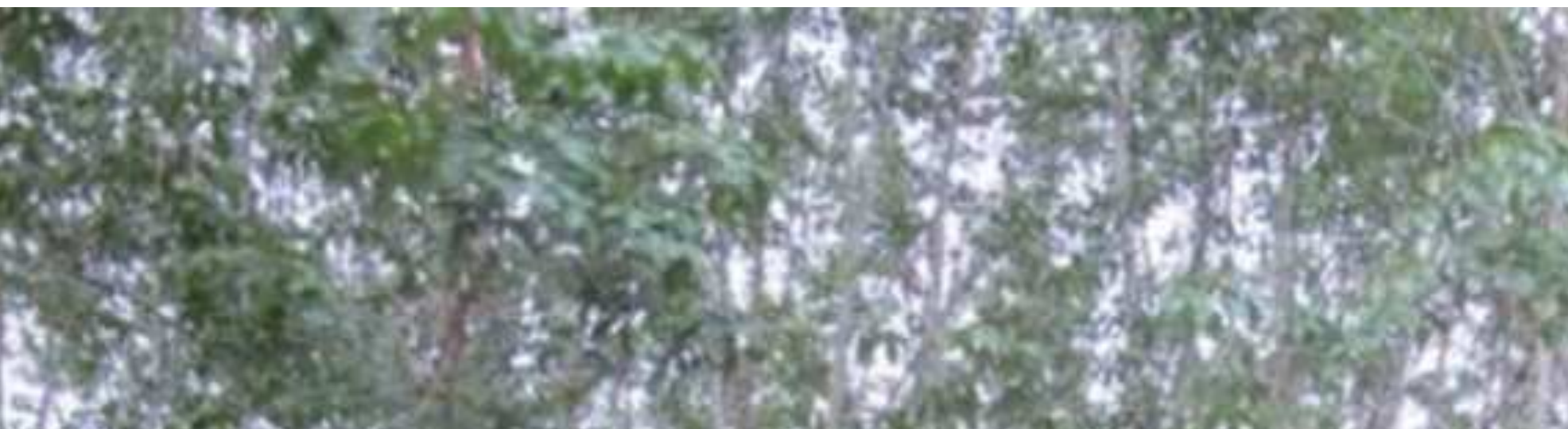

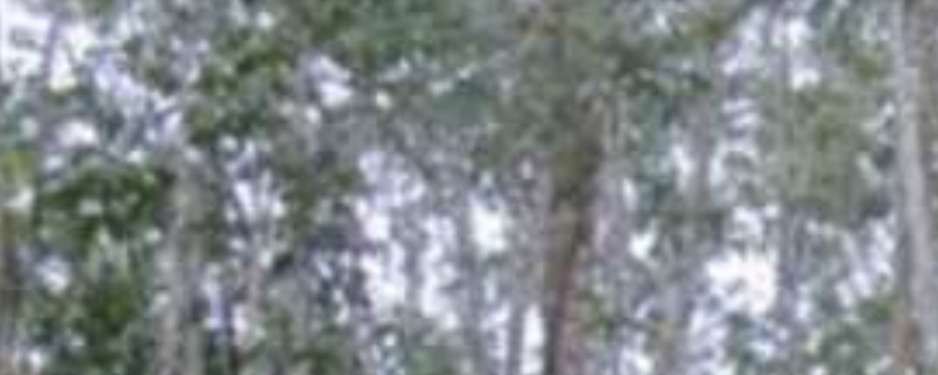

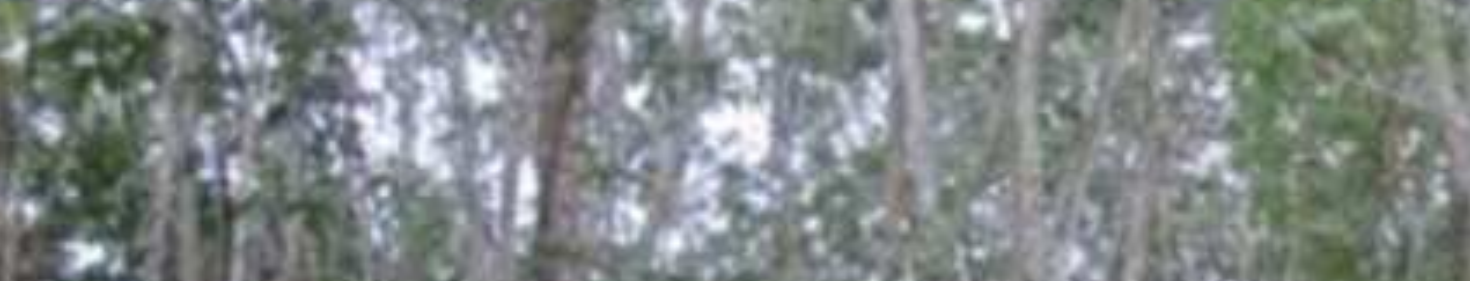

(3) a $10=9$

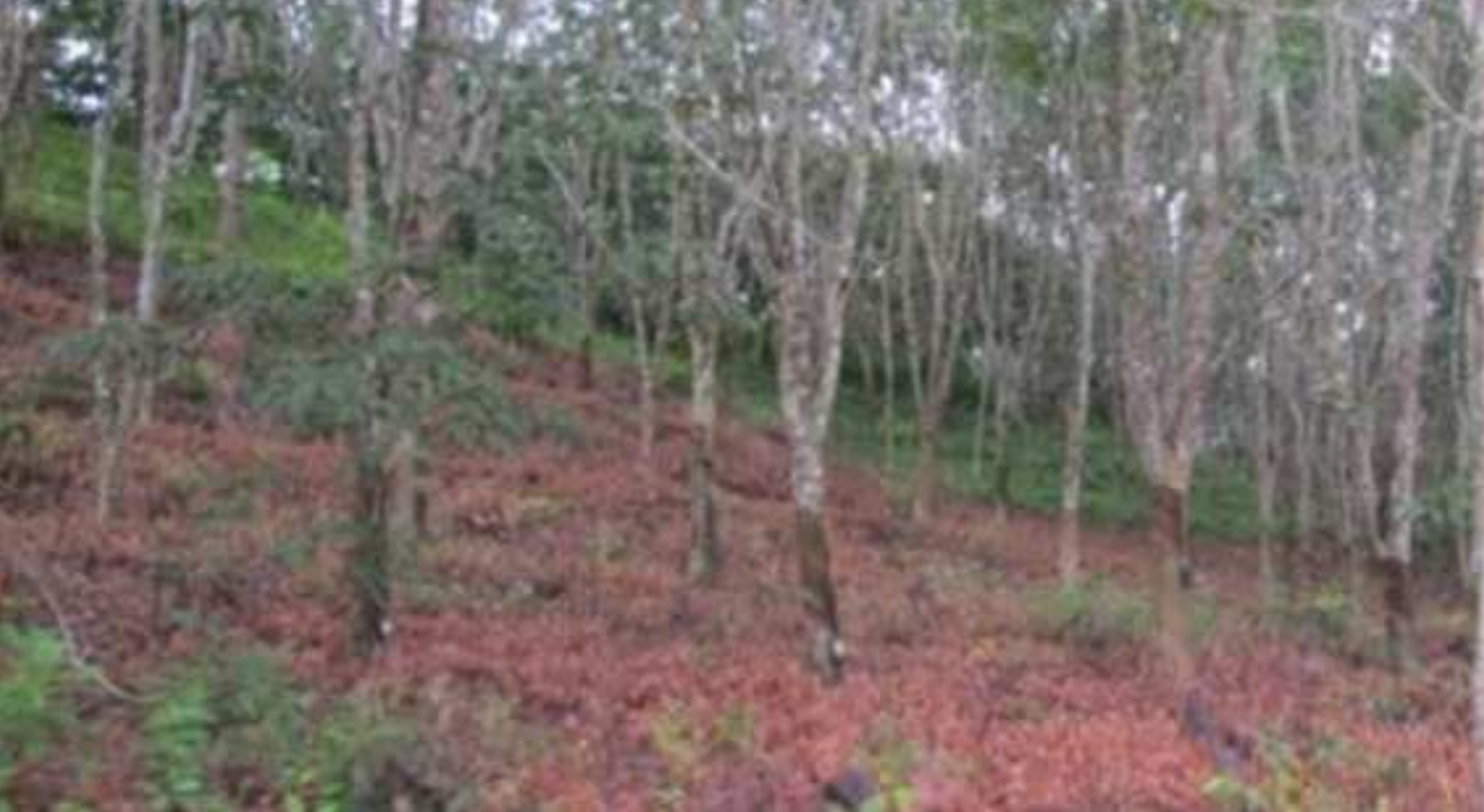

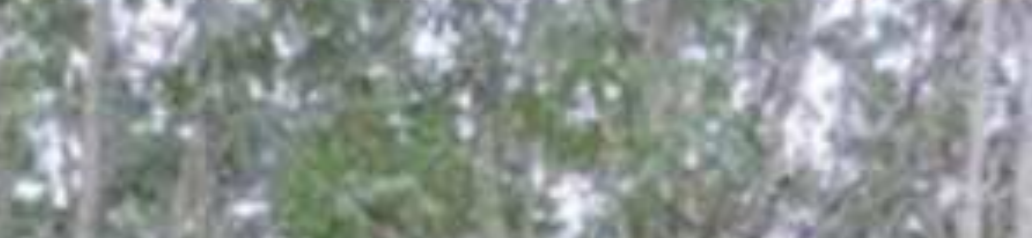

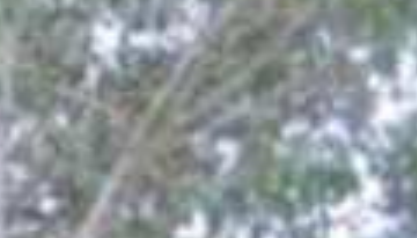

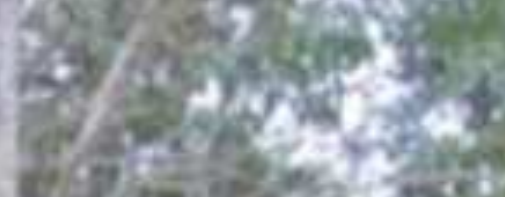

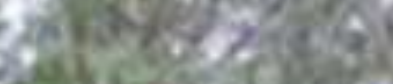

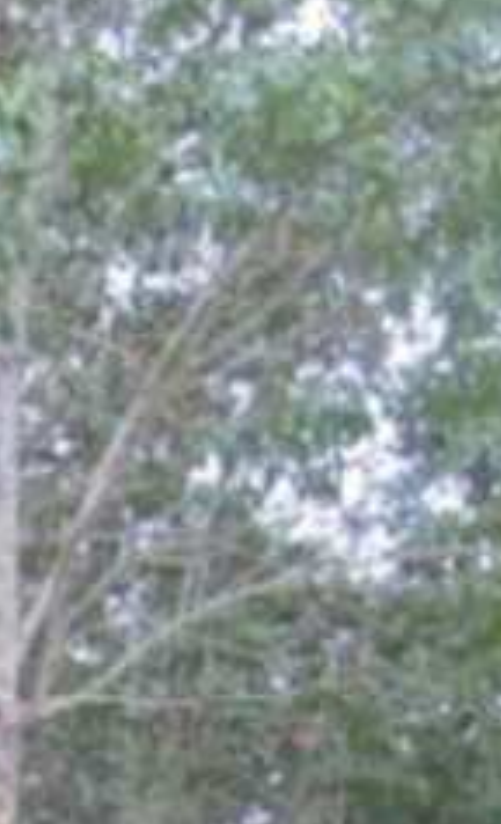

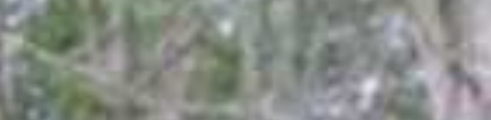
(6)

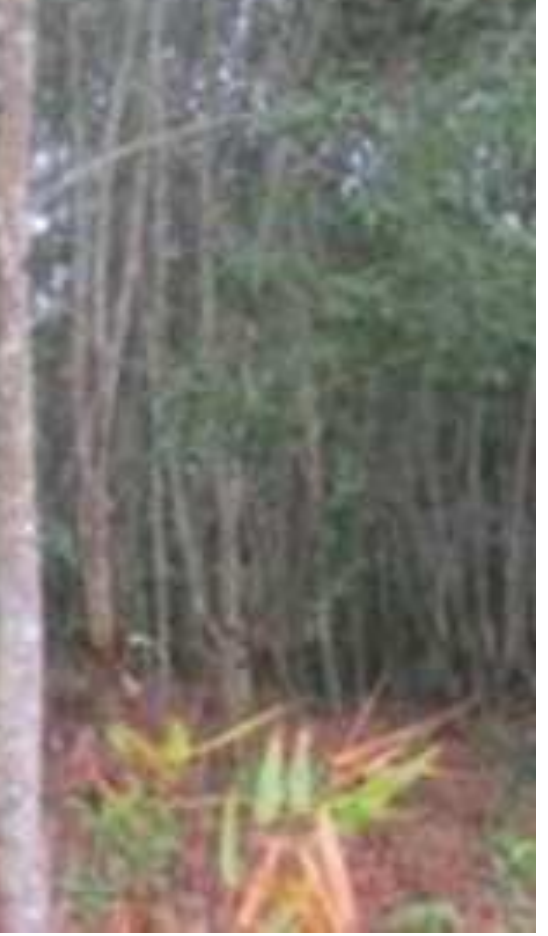

